Check for updates

Cite this: RSC Adv., 2019, 9, 824

Received 18th October 2018 Accepted 29th November 2018 DOI: $10.1039 / c 8 r a 08635 d$

rsc.li/rsc-advances

\section{Recent advances in supported molecular sieve catalysts with wide temperature range for selective catalytic reduction of $\mathrm{NO}_{x}$ with $\mathrm{C}_{3} \mathrm{H}_{6}$}

\begin{abstract}
Junqiang $\mathrm{Xu},(\mathbb{D})^{a}$ Honglin Wang, ${ }^{a}$ Fang Guo, ${ }^{\text {a }}$ Chuan Zhang $^{\mathrm{a}}$ and Jiaqing $\mathrm{Xie}^{\mathrm{b}}$
$\mathrm{NO}_{X}$ is a major atmospheric pollutant that is emanated by motor vehicles, thermal power plants, and industrial boilers. Therefore, the removal of $\mathrm{NO}_{X}$ is a research hotspot in the exhaust gas treatment field. Numerous methods have been used to eliminate $\mathrm{NO}_{x}$ : the selective catalytic reduction of $\mathrm{NO}_{x}$ using $\mathrm{C}_{3} \mathrm{H}_{6}$ as the reducing agent $\left(\mathrm{C}_{3} \mathrm{H}_{6}-\mathrm{SCR}\right)$ is an effective method to remove $\mathrm{NO}_{X}$. The key issue in $\mathrm{NO}_{x}$ removal in $\mathrm{C}_{3} \mathrm{H}_{6}-\mathrm{SCR}$ is to obtain catalysts with low-temperature activity and wide operating temperatures. Till date, different supported wide-temperature-active molecular sieve catalysts have been prepared and used in $\mathrm{C}_{3} \mathrm{H}_{6}-\mathrm{SCR}$ reactions. Studies have shown that the catalytic performance of supported catalysts is related not only to the active component but also to the structural and textural parameters of the molecular sieve supports. This review summarizes the structural and textural characteristics, catalytic properties, and catalytic mechanism of molecular sieve catalysts with different pore structures for $\mathrm{C}_{3} \mathrm{H}_{6}$-SCR reactions. The design strategies of supported molecular sieve catalysts are suggested. The goal of this review is to highlight (1) the structural and textural characteristics and lowtemperature catalytic performance of different supported molecular sieve catalysts; (2) the relationship between wide-temperature window and loaded active components, as well as carriers of the supported molecular sieve catalysts; and (3) design strategies and development prospects of supported molecular sieve catalysts with low-temperature activity and wide-temperature operating range for $\mathrm{C}_{3} \mathrm{H}_{6}-\mathrm{SCR}$ reactions.
\end{abstract}

\section{Introduction}

Nitrogen oxides $\left(\mathrm{NO}_{X}\right)$ in the atmosphere are mainly composed of $\mathrm{NO}(>90 \%)$ and $\mathrm{NO}_{2}$, which mainly come from mobile sources (motor vehicles) and stationary sources (thermal power plants and industrial boilers). Further, they are the main cause for the generation of acid rain and photochemical smog. In

School of Chemistry and Chemical Engineering, Chongqing University of Techno Chongqing 400054, China. E-mail: guofang@cqut.edu.cn; Fax:+86-23-62563460; Tel: +86-23-62563460

${ }^{b}$ School of Chemical and Environmental Engineering, Sichuan College of Technology, Zigong 643000, China

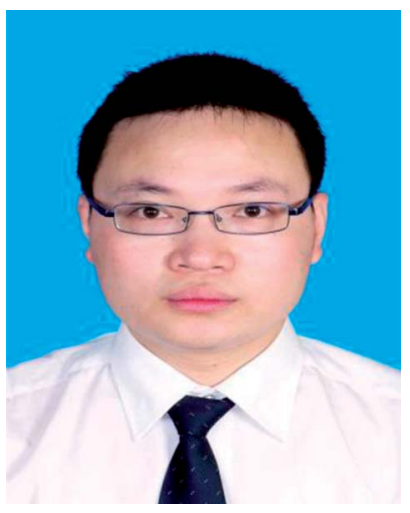

Junqiang $\mathrm{Xu}$ was born in Sichuan, China, in 1979. He obtained his PhD from Sichuan University, Sichuan, China, in 2007 under the supervision of Prof. W. Chu. Now, he is working at the Chongqing University of Technology as Professor. His research interests include energy, chemical, and environmental chemical industries.

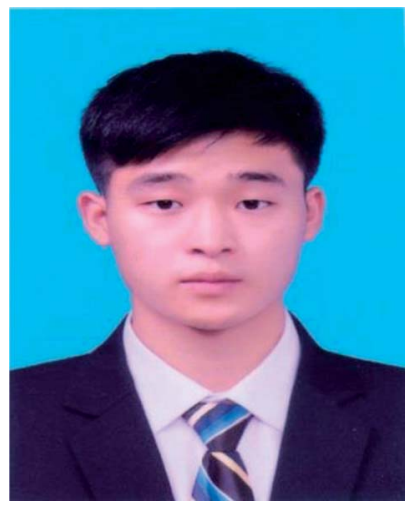

Honglin Wang was born in Chongqing, China, in 1994. He completed his B.S. degree in the Chongqing University of Technology, Chongqing, China, in 2017 under the supervision of Prof. J. Q. Xu. Now, he is studying for his M.S. degree in the Chongqing University of Technology under the supervision of Prof. J. Q. Xu. His field of study is the syntheses and applications of zeolite catalysts 
order to reduce atmospheric pollution, a large number of researchers have dedicated their focus toward the development of de- $\mathrm{NO}_{X}$ technology for high efficiency and low cost. Two methods, $\mathrm{NH}_{3}$-SCR and HC-SCR, have been commonly used to remove $\mathrm{NO}_{X}$. HC-SCR (main component: $\mathrm{C}_{3} \mathrm{H}_{6}$ ) has become an attractive method in the $\operatorname{deNO}_{X}$ of mobile sources because hydrocarbon compounds (HC) are nontoxic and coexist with $\mathrm{NO}_{X}$ in vehicle exhaust. Among the reported HC-SCR reactions, ${ }^{1-6}$ reducing agents mainly contain the hydrocarbons of $\mathrm{C}_{1}, \mathrm{C}_{2}, \mathrm{C}_{3}$, and $\mathrm{C}_{4}$, and universal catalysts mainly include metal oxide catalysts, metal-containing molecular sieve catalysts, and active carbon catalysts.

In the 1990s, Iwamoto group and Held group ${ }^{7,8}$ reported that $\mathrm{C}_{3} \mathrm{H}_{6}$ and other olefins could efficiently and selectively reduce NO using the supported molecular sieve catalysts of Cu-ZSM-5 zeolites under an atmosphere of excess oxygen. Currently, numerous supported molecular sieve catalysts have been widely used in HC-SCR reactions due to their large specific surface area, strong adsorptivity, high selectivity, excellent shape selective catalytic performance, relatively wide active temperature range, etc. ${ }^{\mathbf{9 1 0}}$ The carriers of supported molecular sieve catalysts mainly include $\mathrm{ZSM}-5$, SAPO, SBA, and $\mathrm{Al}_{2} \mathrm{O}_{3}$. Further, the loaded metals of catalysts are usually transition metals, precious metals, and so on.

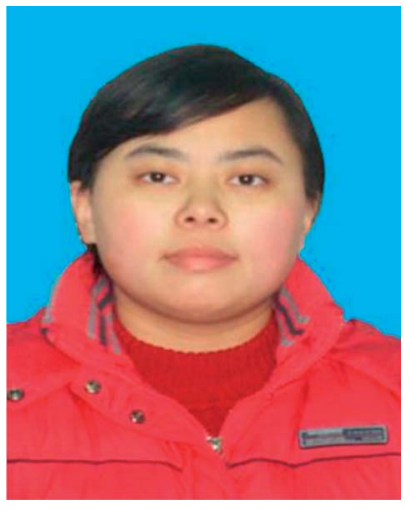

Fang Guo was born in Sichuan, China, in 1982. She received her B.S. degree in 2005; M.S. degree, in 2008; and PhD, in 2011, from Sichuan University, Sichuan, China, under the supervision of Prof. W. Chu. Now, she is working at the Chongqing University of Technology as Associate Professor. Her research interests include design, development, and applications of new catalytic materials.

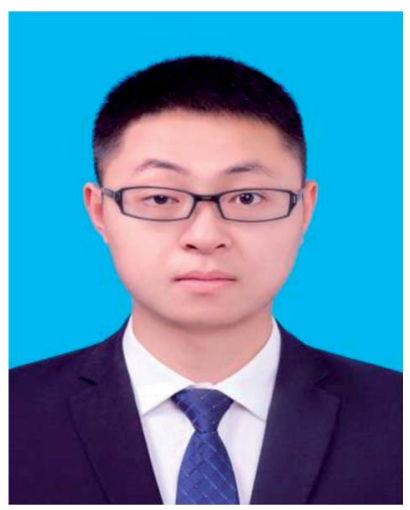

Chuan Zhang was born in Chongqing, China, in 1992. He received his B.S. degree in 2015 and his M.S. degree in 2018 from the Chongqing University of Technology, Chongqing, China, under the supervision of Prof. J. Q. Xu. Now, he is working at China Coal Science and Engineering Group. His field of study is the syntheses of new catalytic materials and their applications in air pollu-
Several reviews regarding the composition and structure of catalysts and the catalytic mechanism of $\mathrm{NH}_{3}$-SCR have been reported in the literature, ${ }^{\mathbf{1 1 - 1 4}}$ but reviews involving the catalytic action of different molecular sieve catalysts have not been reported for HC-SCR so far. This paper reviews the development of supported molecular sieve catalysts for $\mathrm{C}_{3} \mathrm{H}_{6}-\mathrm{SCR}$. This review mainly (1) summarizes the actions of the carriers $\left(\mathrm{Al}_{2} \mathrm{O}_{3}\right.$ and other carriers) and loaded metals (transition metal, rare earths, or precious metals) and the synthesis methods of the supported molecular sieve catalysts with different pore sizes, (2) evaluates the structural characteristics and catalytic performances of supported molecular sieve catalysts with different compositions and pore sizes, (3) discusses the mechanism of $\mathrm{C}_{3} \mathrm{H}_{6}$-SCR over supported molecular sieve catalysts, and (4) attempts to highlight the developing orientations involving supported molecular sieve catalysts with superior lowtemperature activity and wider operating temperatures.

To facilitate the understanding of abbreviations in this paper, the nomenclature of the abbreviations is summarized in Table 1.

\section{Microporous molecular sieve catalysts}

In the 1970s, Mobil Corporation, United States, first synthesized the ZSM-5 molecular sieve with good thermal stability, short pore length, and uniform distribution, and it was widely used as a catalyst carrier. Since then, different types of microporous molecular sieve catalysts have rapidly become a research hotspot.

\subsection{ZSM-5-type zeolite catalysts}

In order to study the effects of different supported metals on a catalyst, Li et al. ${ }^{9}$ prepared three catalysts (Cu-ZSM-5, In-ZSM5, and La-ZSM-5) using H-ZSM-5 as the carrier and Cu, In, and $\mathrm{La}$ as the active components. The catalytic reaction results showed that Cu-ZSM-5 exhibited the best catalytic performance in the case of the three catalysts for $\mathrm{C}_{3} \mathrm{H}_{6}$-SCR, and the conversion of $\mathrm{NO}$ in $\mathrm{C}_{3} \mathrm{H}_{6}$-SCR reached above $70 \%$ over $\mathrm{Cu}-\mathrm{ZSM}$ 5 in the temperature range of $375-500{ }^{\circ} \mathrm{C}$. The DRIFTS results

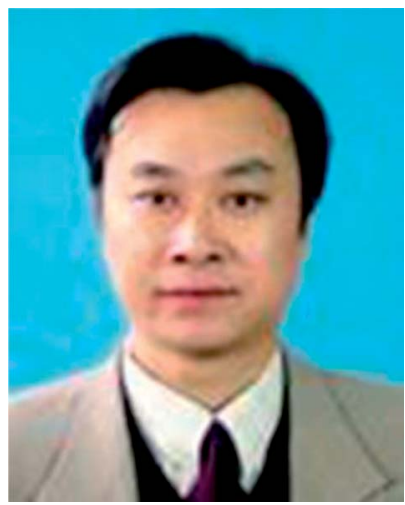

Jiaqing Xie was born in Sichuan, China, in 1959. He completed his $P h D$ in Sichuan University, Sichuan, China, in 2004 under the supervision of Prof. $X . C$. Zeng. Now, he is working at the Sichuan College of Technology as Professor. His research interests include catalytic chemistry, simulated biocatalysts, and nanomaterials.

tion control. 
Table 1 Nomenclature of abbreviations in this paper

\begin{tabular}{|c|c|}
\hline Abbreviation & Nomenclature \\
\hline SCR & Selective catalytic reduction \\
\hline $\mathrm{C}_{3} \mathrm{H}_{6}-\mathrm{SCR}$ & SCR of $\mathrm{NO}_{X}$ using $\mathrm{C}_{3} \mathrm{H}_{6}$ as the reducing agent \\
\hline NTP & Nonthermal plasma \\
\hline $\mathrm{C}_{3} \mathrm{H}_{6}-\mathrm{CO}-\mathrm{SCR}$ & SCR with $\mathrm{C}_{3} \mathrm{H}_{6}$ and $\mathrm{CO}$ as the reducing agents \\
\hline De-NO ${ }_{X}$ & Denitration \\
\hline $\mathrm{NH}_{3}$-SCR & SCR of $\mathrm{NO}_{X}$ using $\mathrm{NH}_{3}$ as the reducing agent \\
\hline HC-SCR & SCR of $\mathrm{NO}_{X}$ using $\mathrm{HC}$ as the reducing agent \\
\hline $\mathrm{NH}_{3}-\mathrm{TPD}$ & $\begin{array}{l}\text { Temperature-programmed desorption with } \\
\text { ammonia }\end{array}$ \\
\hline NO-TPD & TPD with $\mathrm{NO}_{X}$ \\
\hline $\mathrm{H}_{2}$-TPR & Temperature-programmed reaction with $\mathrm{H}_{2}$ \\
\hline TPO & Temperature-programmed oxidation \\
\hline $\mathrm{C}_{x} \mathrm{H}_{y} \mathrm{O}_{z}$ & Hydrocarbon oxide \\
\hline $\mathrm{C}_{x} \mathrm{H}_{y} \mathrm{O}_{z} \mathrm{~N}_{t}$ & Nitrogen-containing hydrocarbon oxide \\
\hline REOs & Rare earth oxides \\
\hline
\end{tabular}

(Fig. 1) indicate that the competitive adsorption between $\mathrm{NO}-\mathrm{O}_{2}$ and $\mathrm{C}_{3} \mathrm{H}_{6}-\mathrm{O}_{2}$ occurs on the Brønsted acid site of the Cu-ZSM-5 catalyst, and the amines $\left(-\mathrm{NH}_{2}\right)$ adsorbed on the Cu-ZSM-5 catalyst surface are the main reaction intermediates that can react with $\mathrm{NO}$ or $\mathrm{NO}_{2}$ to produce the final product $\mathrm{N}_{2}$.

Schuricht et al. ${ }^{10}$ prepared the Ag-ZSM-5 catalyst ( $6 \mathrm{wt} \%$ ) by the impregnation (IM) method using different $\mathrm{Si} / \mathrm{Al}$ ratios of $\mathrm{H}$ ZSM-5 zeolite as the carrier, and they studied the catalytic function of the catalyst. The results showed that NO was effectively reduced to $\mathrm{N}_{2}$ over the catalyst in the temperature range of 380-600 ${ }^{\circ} \mathrm{C}$ in the $\mathrm{C}_{3} \mathrm{H}_{6}$-SCR reaction, and the NO conversion rate was over $50 \%$. The higher the $\mathrm{Si} / \mathrm{Al}$ ratio in the ZSM-5 support, the better is the catalyst activity. This can be attributed to the formation of metallic silver clusters and metallic nanosilver particles at higher metal loadings. These clusters and particles promote the quantitative conversion of $\mathrm{NO}$ to $\mathrm{N}_{2} \mathrm{O}$, and therefore, enhance the activation of the catalyst and NO conversion rate in $\mathrm{C}_{3} \mathrm{H}_{6}$-SCR reactions. UV-vis analysis showed that $\mathrm{Ag}^{+}$is the main species in the $\mathrm{Ag}-\mathrm{H}-\mathrm{ZSM}-5$ catalyst and is highly dispersed.

Seo et al. ${ }^{15}$ prepared a supported microporous zeolite catalyst $\mathrm{Cu}$-ZSM- 5 by the ion-exchange method and used $\mathrm{ZrO}_{2}$-modified

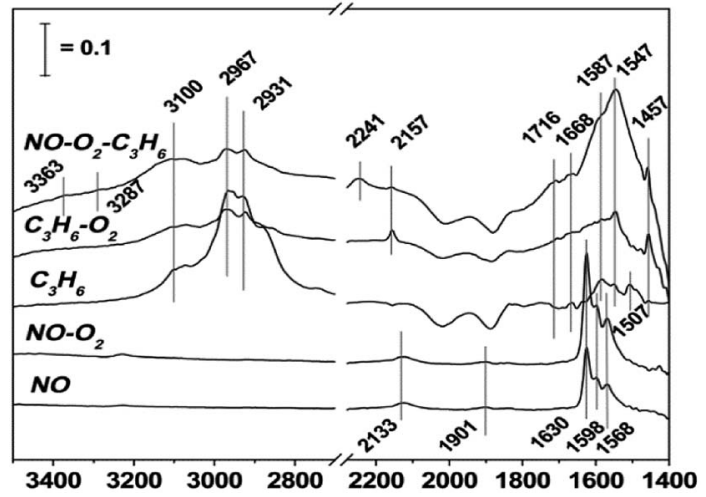

Fig. 1 DRIFTS study of the adsorbed species formed on the surface of the $\mathrm{Cu}$-ZSM- 5 catalyst for NO reduction by propene under reaction conditions at $400{ }^{\circ} \mathrm{C} .{ }^{\circ}$
ZSM-5 as the carrier. The results of the $\mathrm{C}_{3} \mathrm{H}_{6}$-SCR reaction using this catalyst showed that the $\mathrm{NO}$ and $\mathrm{NO}_{2}$ conversion rate was over $50 \%$ at $200-500{ }^{\circ} \mathrm{C}$ when the $\mathrm{ZrO}_{2}$ content in the catalyst was $2 \mathrm{wt} \%$. These results suggest that the $\mathrm{ZrO}_{2}$ promoter promotes the formation of $\mathrm{Cu}^{2+}$, which favors the storage of $\mathrm{NH}_{3}$ in $\mathrm{NH}_{3}$-TPD, and therefore, improves the acidity of the SCR catalyst, thereby enhancing the catalytic performance of the catalyst. The TEM results (Fig. 2) show that the 2 wt $\% \mathrm{ZrO}_{2}$ promoter did not agglomerate on the catalyst, which increased the dispersion of the active component $(\mathrm{Cu})$ on the catalyst.

Komvokis et al. ${ }^{\mathbf{1 6}}$ prepared Cu-ZSM-5 by the ion-exchange method and then prepared the $\mathrm{CeO}_{2}$-coated $\mathrm{CeO}_{2}-\mathrm{Cu}-\mathrm{ZSM}-5$ catalyst by loading $\mathrm{CeO}_{2}$ onto the surface of the Cu-ZSM-5 catalyst. The results of the $\mathrm{C}_{3} \mathrm{H}_{6}$-SCR reaction showed that the NO conversion rate was above $50 \%$ over the $\mathrm{CeO}_{2}$-coated $\mathrm{Cu}$ ZSM-5 catalyst in the temperature range of $330-390{ }^{\circ} \mathrm{C}$. The highest conversion of NO was increased by $40 \%$ as compared to the conversion of uncoated Cu-ZSM- 5 at $350{ }^{\circ} \mathrm{C}$. This can be attributed to the synergistic effect of $\mathrm{Cu}-\mathrm{Ce}$ on the catalyst. The presence of a Ce promoter significantly enhanced the reducibility and electron-giving ability of Cu. XANES-TPR (Fig. 3) also confirmed the synergistic effect between the two metals.

Wang et al. ${ }^{17}$ prepared the La-Cu-ZSM-5 catalyst using a solution ion-exchange method and then obtained the $\mathrm{La}-\mathrm{Cu}-$ ZSM-5/cordierite catalyst by loading La-Cu-ZSM-5 on cordierite. The results of the selective catalytic reduction with $\mathrm{C}_{3} \mathrm{H}_{6}$ and $\mathrm{CO}$ as the reducer $\left(\mathrm{C}_{3} \mathrm{H}_{6}-\mathrm{CO}-\mathrm{SCR}\right)$ indicated that the conversion rates of $\mathrm{NO}$ and $\mathrm{NO}_{2}$ reached over $50 \%$ in the temperature range
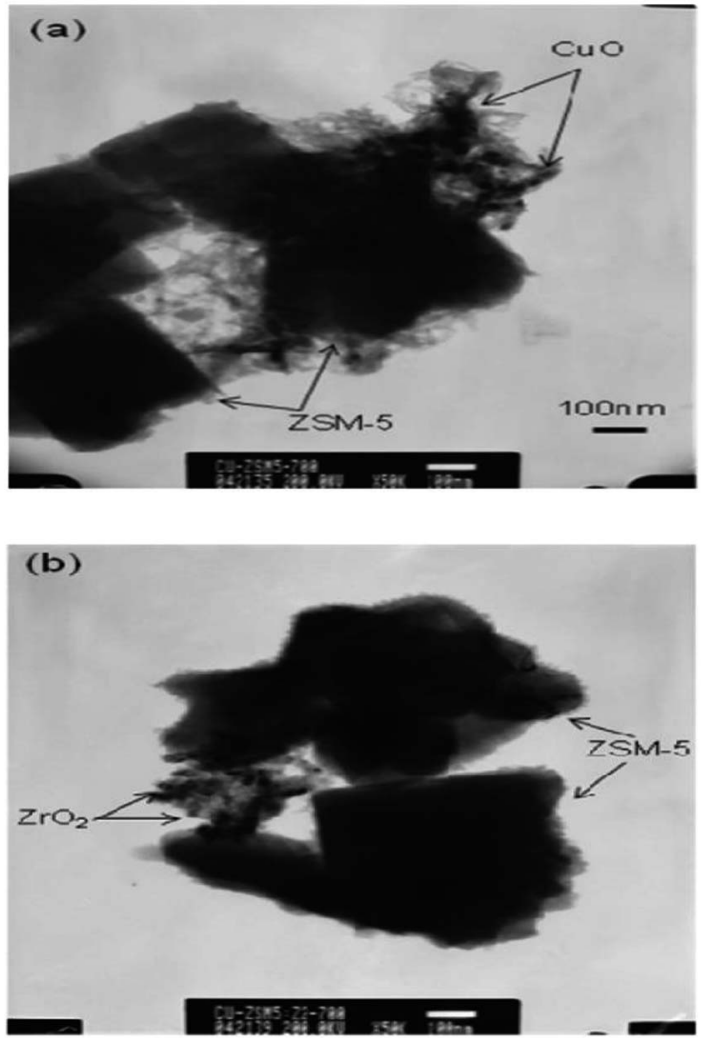

Fig. 2 TEM images of aged $\mathrm{Cu}-\mathrm{ZSM}-5-\mathrm{ZrO}_{2}$ catalysts: (a) Cu-ZSM-5$\mathrm{ZrO}_{2}\left(\mathrm{O} w \mathrm{w} \%\right.$ ) and (b) $\mathrm{Cu}-\mathrm{ZSM}-5-\mathrm{ZrO}_{2}(2 \mathrm{wt} \%){ }^{15}$ 


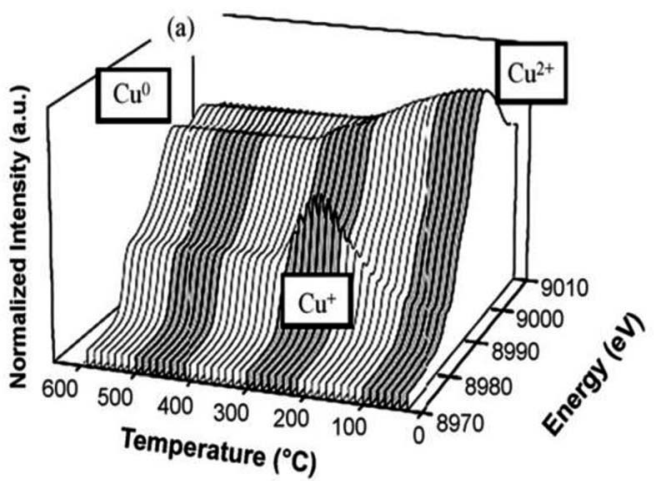

(b)

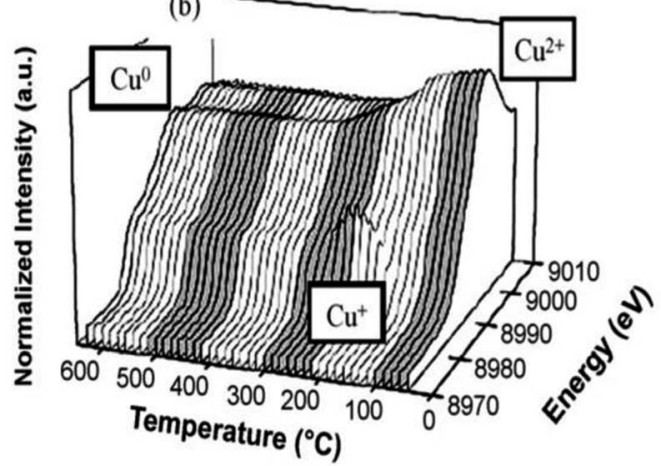

Fig. 3 TPR of (a) Cu-ZSM-5 and (b) $\mathrm{CeO}_{2}-\mathrm{Cu}-\mathrm{ZSM}-5$ as detected by the CuK edge in XANES. ${ }^{16}$

of $210-450{ }^{\circ} \mathrm{C}$, and the maximum conversion rate reached $80 \%$ at $350{ }^{\circ} \mathrm{C}$ under the action of the La-Cu-ZSM-5/cordierite catalyst. In situ FTIR (Fig. 4) spectral results revealed that the $2250 \mathrm{~cm}^{-1}$ band belonged to isocyanate-an important intermediate in the $\mathrm{C}_{3} \mathrm{H}_{6}$-SCR reaction. The introduction of $\mathrm{CO}$ promoted the formation of reaction intermediates and enhanced the ability of $\mathrm{C}_{3} \mathrm{H}_{6}$ activation on La-Cu-ZSM-5/ cordierite, and therefore, increased the $\mathrm{NO}$ and $\mathrm{NO}_{2}$ conversion rates in $\mathrm{C}_{3} \mathrm{H}_{6}$-SCR reactions.

The results of the above studies indicate that the microporous molecular sieve catalysts with ZSM-5 as the carrier are mostly prepared by the ion-exchange and IM methods. The carrier active components on the catalysts are mainly $\mathrm{Cu}, \mathrm{Ag}$, and Fe. Here, $\mathrm{Cu}$ is the best active component to remove NO.

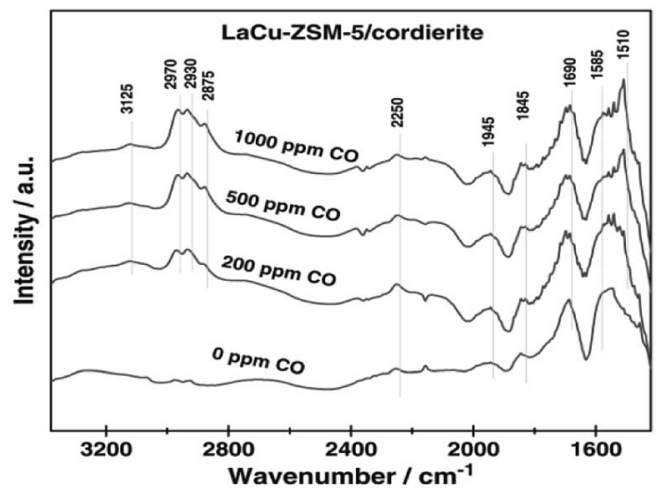

Fig. 4 In situ FTIR spectra of the adsorbed species formed on La-CuZSM-5/cordierite at $523 \mathrm{~K} .^{17}$
The SCR catalytic activity of the molecular sieve catalyst can be improved by loading metal auxiliary agents on the catalyst. For example, the $\mathrm{Zr}$ promoter can improve the catalytic activity of the catalyst by adjusting the acidity of the catalyst; additive in the form of $\mathrm{Ce}$ enhances the reducibility of $\mathrm{Cu}$ through the synergistic effect with $\mathrm{Cu}$, thereby improving the denitration performance of the catalyst. Additive in the form of La can promote the formation of intermediate isocyanates by interacting with $\mathrm{Cu}$, and therefore, enhance the SCR performance of the catalysts. Auxiliaries can also enhance the low-temperature activity of the catalyst through synergy. The ZSM-5 carrier has good ion-exchange ability, high hydrothermal stability, suitable surface acidity, and high shape selectivity. Further, it has a stable structure of a five-membered ring, which favors the interaction with metal active components and auxiliaries. Further, a suitable $\mathrm{Si} / \mathrm{Al}$ ratio allows the active components and auxiliaries to form highly dispersed isolated ionic active sites, thereby improving the catalytic function of the catalyst for denitrification. However, the microporous structure of the ZSM5 carrier is not conducive toward the mass transfer of the macromolecules in the reaction, and they can easily lead to the formation of carbon deposits in the pore, thereby reducing the catalytic performance of the catalyst.

\subsection{Beta-zeolite catalysts}

Pan et al. ${ }^{18}$ prepared Fe-Beta zeolite catalysts by the IM method with $\mathrm{NH}_{4}$ - $\mathrm{Beta}(\mathrm{Si} / \mathrm{Al}=25)$ as the carrier. The $\mathrm{C}_{3} \mathrm{H}_{6}$-SCR reaction results showed that the $\mathrm{NO}$ and $\mathrm{NO}_{2}$ conversion rates reached more than $50 \%$ over the catalyst in the temperature range of $290-390{ }^{\circ} \mathrm{C}$, and the maximum conversion rate reached $75 \%$ at $350{ }^{\circ} \mathrm{C}$. This is attributed to the strong adsorption for $\mathrm{C}_{3} \mathrm{H}_{6}$ and the high $\mathrm{Fe}^{2+} / \mathrm{Fe}^{3+}$ ratio on the Fe-Beta zeolite catalyst surface. The XPS and $\mathrm{H}_{2}$-TPR results (Fig. 5) confirmed that $\mathrm{Fe}^{3+}$ was almost reduced to $\mathrm{Fe}^{2+}$ on the Beta carrier, which favors the activation of $\mathrm{C}_{3} \mathrm{H}_{6}$, and therefore, promoted the denitrification in $\mathrm{C}_{3} \mathrm{H}_{6}$-SCR.

In order to improve the low-temperature activity of Betazeolite catalysts, Cortés et al. ${ }^{19}$ prepared a Pt-Beta zeolite catalyst by the ion-exchange method with $\mathrm{NH}_{4}-\beta(\mathrm{Si} / \mathrm{Al}=11.4)$ as the carrier. The results of the $\mathrm{C}_{3} \mathrm{H}_{6}-\mathrm{SCR}$ reaction using this catalyst showed that the $\mathrm{NO}$ and $\mathrm{NO}_{2}$ conversion rates exceeded $50 \%$ in

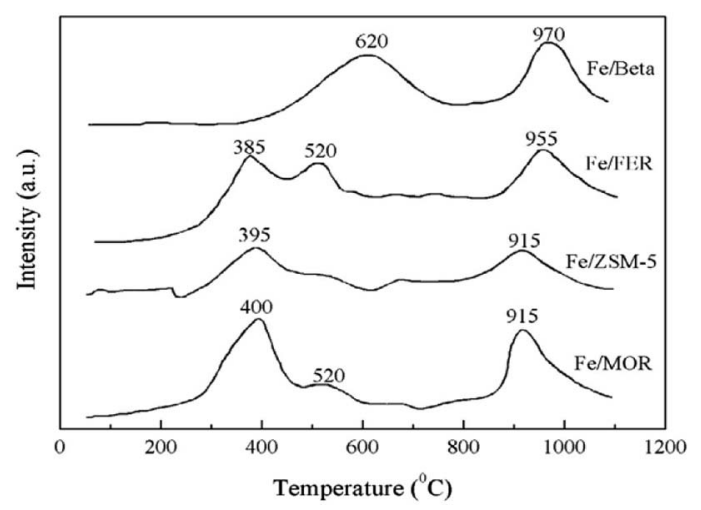

Fig. 5 TPR profile of Fe-zeolite catalysts. ${ }^{18}$ 
the temperature range of $210-260{ }^{\circ} \mathrm{C}$, and the maximum conversion rate was $75 \%$ at $220{ }^{\circ} \mathrm{C}$. The XPS and FTIR results reveal that the interaction between $\mathrm{Pt}$ and Beta zeolite promoted the adsorption and activation of $\mathrm{C}_{3} \mathrm{H}_{6}$ and formed the $\mathrm{C}_{x} \mathrm{H}_{y} \mathrm{O}_{z}$ reaction intermediate, which promoted the denitrification of the catalyst in $\mathrm{C}_{3} \mathrm{H}_{6}$-SCR.

In addition, Nejar et al. $^{20}$ also prepared zeolites $\mathrm{K}-\mathrm{Cu}-\mathrm{Beta}$ and $\mathrm{K}$-Co-Beta with a Beta-zeolite carrier. The $\mathrm{C}_{3} \mathrm{H}_{6}-\mathrm{SCR}$ results revealed that the conversion rates of $\mathrm{NO}$ and $\mathrm{NO}_{2}$ on the $\mathrm{K}$-Co-Beta catalyst exceeded $50 \%$ in the temperature range of $330-500{ }^{\circ} \mathrm{C}$, and the conversion rates of $\mathrm{NO}$ and $\mathrm{NO}_{2}$ on the $\mathrm{K}-$ $\mathrm{Cu}$-Beta catalyst exceeded $80 \%$ in the temperature range of $300-$ $500{ }^{\circ} \mathrm{C}$. The $\mathrm{H}_{2}$-TPR and XPS results revealed that $\mathrm{K}$ enhanced the reduction of $\mathrm{CuO}$. The main peak at $933.6 \mathrm{eV}$ corresponds to $\mathrm{CuO}$; this peak shifts to lower $\mathrm{BE}$ due to the interaction of $\mathrm{Cu}$ with an electropositive element, such as K. Further, the shoulder at around $936.0 \mathrm{eV}$ can be assigned to ionic-exchanged $\mathrm{Cu}^{2+}$ on the Beta-zeolite or, at least, to $\mathrm{CuO}$ with a more intense interaction with the Beta-zeolite support. Therefore the synergistic effect of $\mathrm{K}-\mathrm{Cu}$ promoted the strong interaction between Beta-zeolite and $\mathrm{Cu}$ species $\left(\mathrm{Cu}^{2+}, \mathrm{CuO}\right)$, significantly improving the redox performance of $\mathrm{Cu}$ species on $\mathrm{K}-\mathrm{Cu}$-Beta catalyst, and therefore, enhances the catalytic performance of the catalyst. For Co-based catalysts, a similar relation between the $\mathrm{K}$ content and catalysts activity is observed, but the effect of $\mathrm{K}$ is less pronounced than that of $\mathrm{Cu}$ catalysts.

From the results of the above literatures, it can be observed that nonnoble metal active components supported by beta molecular sieves are mainly $\mathrm{Cu}, \mathrm{Fe}$, and $\mathrm{Co}$ in the catalysts, among which the preferred active component is $\mathrm{Cu}$. Beta-zeolite is a unique three-dimensional zeolite with a twelve-membered ring channel and strong acidic characteristic, which can enhance the $\mathrm{NO}_{X}$-adsorbing capability on the surface of the catalyst and the synergy between the carrier and active component, thereby significantly enhancing the redox properties of the active component species, and therefore, improving the catalytic performance of the catalyst. However, its crystal structure is very complex and easily leads to the formation of carbon deposits during the reaction process.

\subsection{SAPO-34 molecular sieve catalysts}

Li et al. ${ }^{21}$ fabricated SAPO-34 molecular sieves with different $\mathrm{Si}$ / $\mathrm{Al}$ ratios by the hydrothermal synthesis method and then prepared the Cu-SAPO-34 catalyst by the ion-exchange method using SAPO-34 as the carrier. The $\mathrm{C}_{3} \mathrm{H}_{6}$-SCR results revealed that the greater the $\mathrm{Si} / \mathrm{Al}$ ratio, the better is the SCR activity. In the presence of the catalyst with a $\mathrm{Si} / \mathrm{Al}$ ratio of 0.8 , the $\mathrm{NO}$ conversion increased $5-30 \%$ at $300-450{ }^{\circ} \mathrm{C}$ (as compared to $\mathrm{Si} / \mathrm{Al}$ $=0.4$ ) and $\mathrm{NO}$ conversion reached $70 \%$ at the highest point in the $\mathrm{C}_{3} \mathrm{H}_{6}$-SCR results. SEM (Fig. 6) and $\mathrm{NH}_{3}$-TPD results revealed that the molecular sieve $(\mathrm{Si} / \mathrm{Al}=0.8)$ had the best morphology regularity and smoothness on the particle surface, and the particles were more evenly dispersed on the catalyst, thereby increasing the number of effective acid sites on the molecular sieve skeleton and acid strength, which favors the increase in the denitrification of the catalyst in $\mathrm{C}_{3} \mathrm{H}_{6}$-SCR.

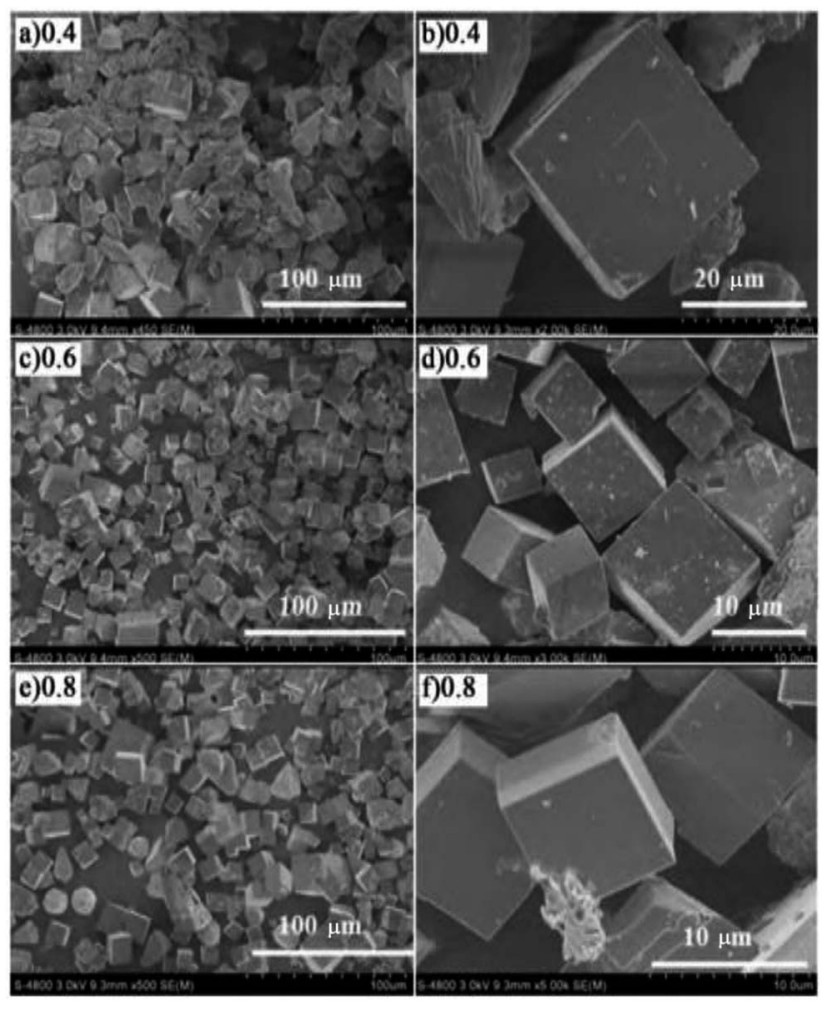

Fig. 6 SEM images of SAPO-34 zeolites with different Si/Al ratios. ${ }^{21}$

In order to compare the catalytic functions of the catalysts prepared by different synthesis methods, Zuo et al. ${ }^{22}$ adopted hydrothermal synthesis, pore volume IM, and ion-exchange methods to yield Cu-SAPO-34 with SAPO-34 as the carrier. The $\mathrm{C}_{3} \mathrm{H}_{6}$-SCR reaction results revealed that the conversion rate of NO on the catalysts prepared by the ion-exchange method increased by $5-22 \%$ and $10-30 \%$ when compared with the catalysts prepared by the pore volume IM and hydrothermal syntheses, respectively, in the temperature range of $100-300{ }^{\circ} \mathrm{C}$. The SEM results revealed that the SAPO-34 support had a certain degree of regularity and roughness on its crystal structure, and the active constituent $(\mathrm{Cu})$ on the catalyst prepared by the ion-exchange method exhibited high dispersity, thereby providing more active sites, and therefore, improving the catalytic performance of the catalyst.

Furthermore, $\mathrm{Lv}^{23}$ used hydrothermal synthesis to fabricate SAPO-34 molecular sieves with different silicon sources and then prepared the Cu-SAPO-34 catalyst by the ion-exchange method. The $\mathrm{C}_{3} \mathrm{H}_{6}$-SCR reaction results revealed that the NO conversion rate on the catalyst prepared using a silica sol as the silicon source reached over $50 \%$ in the temperature range of $325-450{ }^{\circ} \mathrm{C}$, and the maximum conversion rate reached $70 \%$ at $350{ }^{\circ} \mathrm{C}$. As compared to the catalyst prepared using ethyl orthosilicate as the silicon source, NO conversion increased by $10 \%$ over the catalyst in the temperature range of $350-450{ }^{\circ} \mathrm{C}$. The SEM and DRIFTS results revealed that the interaction between the SAPO-34 molecular sieve and the active components of the catalyst prepared with the silica sol as the silicon source promoted the formation of the reaction intermediate $-\mathrm{CN}$, which favored the production of more $\mathrm{N}_{2}$, and therefore, promoted SCR activity. 
The above research results show that the main active component supported by SAPO-34 molecular sieve catalyst is mainly $\mathrm{Cu}$; the catalyst preparation method can influence the dispersion degree of the active component supported by SAPO34 , and therefore, change the catalytic performance and catalytic temperature range of the catalyst. The silicon source and $\mathrm{Si} / \mathrm{Al}$ ratio of the SAPO-34 molecular sieve are also important factors affecting the catalytic performance of the catalyst. The SAPO-34 molecular sieve has intermediate strength with regard to the acid center, a unique pore structure, a large number of micropores, and a high specific surface area; therefore, the catalyst with a SAPO-34 molecular sieve yields additional active sites and promotes interactions between the SAPO-34 molecular sieve and the active component, and therefore, enhances the catalytic performance of the catalyst. However, the synthesis of SAPO-34 molecular sieve is very complicated, such as raw materials, templating agents, and other variable factors; therefore, it is very important to screen suitable synthesis conditions during the synthesis of pure phase and high-crystallinity molecular sieves.

\subsection{SSZ-13 molecular sieve catalysts}

Raj et al. ${ }^{24}$ studied the $\mathrm{C}_{3} \mathrm{H}_{6}$-SCR reaction on a Cu-SSZ-13 monolithic catalyst using a small-scale flow reactor. The results showed that the NO conversion rate reached over $50 \%$ at 380-550 ${ }^{\circ} \mathrm{C}$ under the action of the catalyst, and the highest value obtained was $90 \%$. The DRIFTS results showed that the partially oxidized $\mathrm{C}_{3} \mathrm{H}_{6}$ in the hydrocarbon reacted with NO to form the intermediate ANCO, and the intermediate reacted with $\mathrm{O}_{2}$ to form $\mathrm{N}_{2}$, thereby promoting the conversion of NO under catalytic action within a certain temperature range.

In addition, Kim et al. ${ }^{25}$ studied the $\mathrm{C}_{3} \mathrm{H}_{6}$-SCR reaction on the Cu-SSZ-13 catalyst using dynamic adsorption and TPD (Fig. 7) methods. The results revealed that there were two different adsorption energies of $4.4 \mathrm{~kJ} \mathrm{~mol}^{-1}$ and $70.9 \mathrm{~kJ} \mathrm{~mol}^{-1}$ in the temperature range of $72-544^{\circ} \mathrm{C}$. Therefore, the Cu-SSZ-13 catalyst exhibited a significant adsorption capacity for propylene and was favorable toward the SCR activity of the catalyst.

Raj et al. ${ }^{26}$ investigated the $\mathrm{C}_{3} \mathrm{H}_{6}$-SCR reaction on the Cu-SSZ13 monolithic catalyst using a benchtop flow reactor. The reaction results revealed that the $\mathrm{NO}_{2}$ conversion rate reached

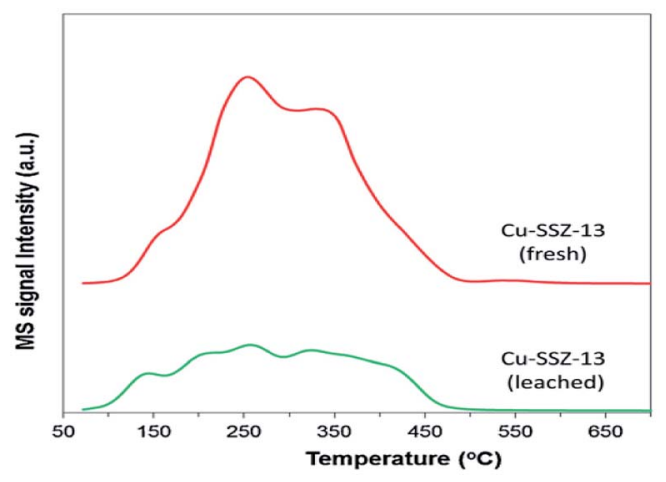

Fig. $7 \mathrm{C}_{3} \mathrm{H}_{6}$-TPD profiles of fresh and leached $\mathrm{Cu}$-SSZ-13 catalysts. ${ }^{25}$ over $80 \%$ in the temperature range of $260-550{ }^{\circ} \mathrm{C}$. The DRIFTS results indicated that the interaction of the active component (Cu) with the SSZ-13 support enhanced the selective reaction of $\mathrm{NO}_{2}$ with the oxygen-containing compound, forming a further $\mathrm{C}_{x} \mathrm{H}_{y} \mathrm{O}_{z} \mathrm{~N}_{t}$ compound. This promoted the formation of the reaction intermediate $-\mathrm{NCO}$ and further generation of additional $\mathrm{N}_{2}$.

Studies involving SSZ-13 molecular sieve catalysts are rare so far, and the most common supported active component of the catalyst is $\mathrm{Cu}$. The catalytic performance of the SSZ-13 molecular sieve catalyst is higher than that of the other types of microporous molecular sieve catalysts. The SSZ-13 molecular sieve has an ordered pore structure, with additional surface protonic acidic sites and exchangeable cations. In the $\mathrm{C}_{3} \mathrm{H}_{6}$-SCR reaction, the reaction activities of $\mathrm{NO}_{X}$ and oxygenated hydrocarbons is enhanced by the strong interaction between the SSZ13 carriers and the active component $(\mathrm{Cu})$, thereby promoting the formation of the intermediates ANCO and -NCO, which generates additional $\mathrm{N}_{2}$. However, it is difficult to control its acidity and the problem of carbon deposition under hightemperature conditions.

Microporous molecular sieves have large specific surface areas, high hydrothermal stability, and suitable surface acidity; therefore, the support catalyst on the sieves can effectively remove $\mathrm{NO}_{X}$ in $\mathrm{C}_{3} \mathrm{H}_{6}$-SCR. Nevertheless, the pore structure of the microporous molecular sieves is small and complex, which limits the mass transfer in the SCR reaction, which facilitates the formation of carbon deposits and sulfides in the pores of microporous molecular sieves; this results in the deactivation of the catalyst. Therefore, investigating zeolite catalysts with larger pore size is very important for improving the catalytic performance of the catalyst.

\section{Mesoporous molecular sieve catalysts}

In 1992, Mobil Petroleum Corporation first synthesized M41s mesoporous molecular sieves, which opened up a new era in the study of mesoporous molecular sieves and supported catalysts.

\subsection{SBA-type catalysts}

SBA-15 is usually used as a mesoporous molecular sieve carrier. Liu et $a .^{27}$ used the IM method to prepare the Pt-SBA-15 catalyst with SBA- 15 as the carrier. The $\mathrm{C}_{3} \mathrm{H}_{6}$-SCR results showed that the Pt-SBA15 catalyst had good catalytic performance in the temperature range of $130-340{ }^{\circ} \mathrm{C}$, and the conversion rates of $\mathrm{NO}$ and $\mathrm{NO}_{2}$ in the presence of the catalyst exceeds $50 \%$. This can be attributed to the interaction between the SBA-15 support and the active component (Pt) at lower temperatures. This action promoted the redox properties of the Pt species and enhanced the activation of $\mathrm{C}_{3} \mathrm{H}_{6}$ and adsorption rates of $\mathrm{NO}$ and $\mathrm{NO}_{2}$. Therefore, the Pt-SBA-15 catalyst exhibited high catalytic function in $\mathrm{C}_{3} \mathrm{H}_{6}$-SCR. The XPS results revealed that $\mathrm{Pt}, \mathrm{PtO}$, and $\mathrm{PtO}_{2}$ were present in the catalyst, and $\mathrm{PtO}_{2}$ may be the main active center of Pt-SBA-15. NO-TPD (Fig. 8) showed that the lowest desorption amount on Pt-SBA-15 was three times the maximum desorption amount on SBA-15 in the 


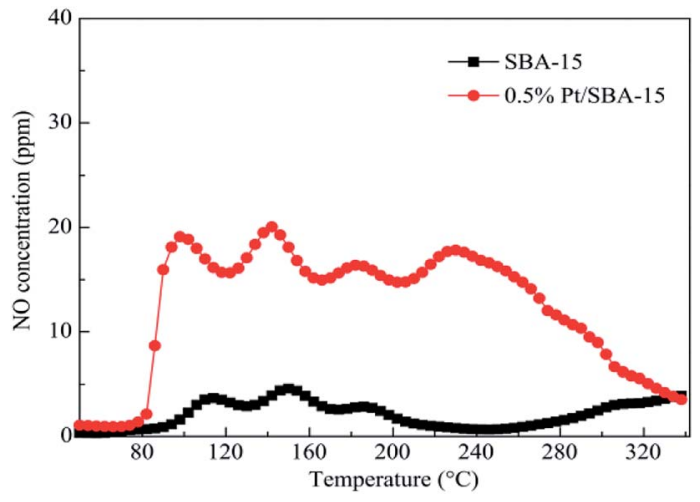

Fig. 8 NO-TPD profiles of SBA-15 and 0.5\% Pt-SBA-15. ${ }^{27}$

temperature range of $85-260{ }^{\circ} \mathrm{C}$, which suggested that the $\mathrm{Pt}$ loaded on SBA- 15 favored the adsorption of $\mathrm{NO}$ and $\mathrm{NO}_{2}$. The study results also revealed that the introduction of $\mathrm{Al}$ assistant suitably enhanced the catalytic function of Pt-SBA-15. The maximum conversion rates of $\mathrm{NO}$ and $\mathrm{NO}_{2}$ reached $86 \%$, which, for Pt-AlSBA- 15 , is $6 \%$ greater than that for pure Pt-SBA- 15 at $140{ }^{\circ} \mathrm{C}$. It is believed that the $\mathrm{AlO}_{4}$ tetrahedral coordination in the Pt-Al-SBA-15 catalyst enhanced the surface acidity of the catalyst, thereby improving the catalytic performance and stability of the catalyst.

In order to study the effect of different supported metals and bimetallic synergistic effect on the catalyst, Zhang et al. ${ }^{28}$ prepared a series of M-SBA- 15 and $\mathrm{M}_{2}$-SBA- 15 catalysts using a single metal $\mathrm{M}(\mathrm{M}=\mathrm{Cu}, \mathrm{Fe}, \mathrm{Cr}$, or $\mathrm{Al})$ or bimetallic $\mathrm{M}_{2}\left(\mathrm{M}_{2}=\right.$ $\mathrm{Cu}-\mathrm{Al}$, Fe-Al, or $\mathrm{Cr}-\mathrm{Al}$ ) as the active component. The $\mathrm{C}_{3} \mathrm{H}_{6}$-SCR results revealed that the Fe-SBA-15 catalyst exhibited the best catalytic performance in the four single-metal catalysts; the NO conversion rate exceeded $50 \%$ in the temperature range of $410-$ $600{ }^{\circ} \mathrm{C}$ and the maximum reached $90 \%$ at $600{ }^{\circ} \mathrm{C}$ in the presence of Fe-SBA-15. For the bimetallic catalysts, the Cu-Al-SBA-15 catalyst exhibited the best catalytic function; the NO conversion rate exceeded $50 \%$ in the temperature range of $330-600{ }^{\circ} \mathrm{C}$, and the maximum conversion rate was close to $100 \%$ at $450{ }^{\circ} \mathrm{C}$ in the presence of the $\mathrm{Cu}-\mathrm{Al}-\mathrm{SBA}-15$ catalyst. The results indicated that the bimetallic synergistic effect enhanced the maximal conversion rate of $\mathrm{NO}$ and reduced the optimum catalytic temperature in $\mathrm{C}_{3} \mathrm{H}_{6}-\mathrm{SCR}$. The $\mathrm{H}_{2}$-TPR results further confirmed that the Cu-Al-SBA-15 catalysts exhibited better redox properties as compared to Fe-SBA-15, and therefore, have superior catalytic performance with regard to SCR.

Sabbaghi et al. ${ }^{29}$ fabricated SBA-15 molecular sieves by hydrothermal synthesis and the Co-Zr-SBA- 15 catalyst by the IM method using SBA-15 as the carrier. The $\mathrm{C}_{3} \mathrm{H}_{6}$-SCR results revealed that the NO conversion rate exceeded $50 \%$ in the presence of the catalyst within the temperature range of 330$375{ }^{\circ} \mathrm{C}$. The XRD and XPS results reveal that the active components, namely, $\mathrm{Zr}$ and $\mathrm{Co}$, were uniformly dispersed on the surface of the support, which enhanced the interaction between the active component and the support, as well as promoted the synergistic redox properties of $\mathrm{Zr}$ and Co. This facilitated the improvement in the surface acidity of the catalyst and enhanced the catalytic performance of the catalyst.
The above studies indicate that the commonly supported active components of the SBA- 15 catalyst are $\mathrm{Fe}, \mathrm{Pt}, \mathrm{Cu}$, and $\mathrm{Co}$, and the SCR catalytic activity of the catalyst can be improved by the synergistic interactions between the promoter and the polyactive center in the bimetallic catalyst. Further, the synergy between the multiple active sites can reduce the activation temperature of the catalyst. The SBA-15 molecular sieve has a two-dimensional hexagonal pore structure, and the silica dioxide on the skeleton is generally amorphous. This kind of molecular sieve has a larger surface area, uniform pore diameter distribution, and adjustable pore diameter, which is favorable for the uniform dispersion of the active component on the surface of the carrier, thereby enhancing the interaction between the active component and molecular sieve, as well as promoting the redox performance of the active component. This improves the catalytic performance of the catalyst. However, there are only a few acid active sites in the skeleton, and the problem of poor ion-exchange capacity is more prominent.

\subsection{MCM-type catalyst}

Kim et $a l .{ }^{30}$ first synthesized a MCM-41 molecular sieve support by hydrothermal synthesis and then prepared the Pt-MCM-41 catalyst by the IM method. The $\mathrm{C}_{3} \mathrm{H}_{6}$-SCR reaction results revealed that the NO conversion rate exceeded $50 \%$ in the presence of the catalyst within the temperature range of 150$500{ }^{\circ} \mathrm{C}$, and they reached the maximum conversion rate of $79 \%$ at $225{ }^{\circ} \mathrm{C}$. The good catalytic performance of the Pt-MCM- 41 catalyst in a wide temperature range could be attributed to the good redox performance of the Pt species and the better adsorption of $\mathrm{NO}$ on the catalyst surface. In the reduction process, ONO and NCO intermediates are produced, which then react with $\mathrm{O}_{2}$ to generate additional $\mathrm{N}_{2}$. The XPS and DRIFTS results further confirm that $\mathrm{Pt}$ had a strong redox performance in the reaction; $\mathrm{PtO}_{2}$ species were the main active sites and promoted the formation of the $\mathrm{NO}_{2}$, ONO, and NCO intermediates in the reaction through the partial oxidation mechanism.

Wan et al. ${ }^{31}$ used the hydrothermal synthesis method to fabricate the $\mathrm{Cu}-\mathrm{Al}-\mathrm{MCM}-41$ catalyst with $\mathrm{MCM}-41$ as the carrier. The $\mathrm{C}_{3} \mathrm{H}_{6}$-SCR reaction results revealed that the NO conversion exceeded $50 \%$ in the presence of this catalyst within the temperature range of $300-430{ }^{\circ} \mathrm{C}$, and it reached the maximum of $78 \%$ at $360{ }^{\circ} \mathrm{C}$. The $\mathrm{H}_{2}$-TPR (Fig. 9) and NO-TPD results indicate that the strong interaction between $\mathrm{Cu}-\mathrm{Al}$ and MCM-41 support enhanced the synergistic redox properties between the $\mathrm{Cu}$ species $\left(\mathrm{Cu}^{2+}, \mathrm{Cu}^{+}, \mathrm{CuO}\right.$, etc. $)$ and $\mathrm{Al}$, consequently promoting the desorption and activity of NO on the catalyst surface.

Jeon et al. ${ }^{32}$ prepared a MCM- 41 molecular sieve by hydrothermal synthesis and then used the IM method to prepare the Pt-V-MCM-41 catalyst. The $\mathrm{C}_{3} \mathrm{H}_{6}$-SCR results revealed that the conversion rate of NO exceeded $50 \%$ under the effect of this catalyst in the temperature range of $260-480{ }^{\circ} \mathrm{C}$, particularly achieving the maximum conversion rate of $90 \%$ in the temperature range of $270-340{ }^{\circ} \mathrm{C}$. The TPO and FTIR results indicate that the V-doped species on the MCM-41 surface 


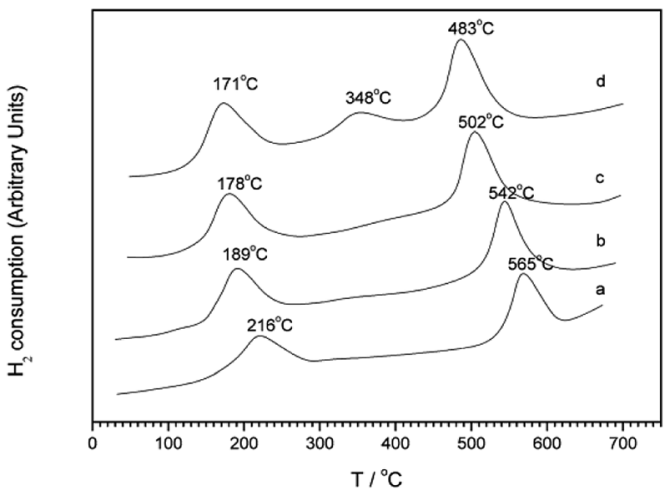

Fig. $9 \mathrm{H}_{2}$-TPR profiles of $\mathrm{Cu}-\mathrm{Al}-\mathrm{MCM}-41$ samples with $\mathrm{Si} / \mathrm{Al}=10$ : (a) Cu-Al-MCM-41-10-31, (b) Cu-Al-MCM-41-10-61, (c) Cu-Al-MCM41-10-93, and (d) Cu-Al-MCM-41-10-120. ${ }^{31}$

promoted the adsorption of NO on the catalyst surface and improved the redox performance of Pt due to the synergistic effect between Pt, V, and MCM-41 molecular sieve support. Meanwhile, the synergistic effect promoted the adsorption and activity of $\mathrm{C}_{3} \mathrm{H}_{6}$; therefore, the Pt-V-MCM-41 catalyst exhibited high catalytic performance.

The above results show that the active components supported by MCM- 41 as the carrier are mostly $\mathrm{Cu}$ and $\mathrm{Pt}$, where the preferred active component is Pt. The V adjuvant can bind to MCM-41 by bonding with the hydroxyl of the pore wall surface, producing the synergistic effect with the active constituent $(\mathrm{Pt})$. This can significantly improve the catalytic performance of the catalyst for $\mathrm{C}_{3} \mathrm{H}_{6}$-SCR in the low-temperature range of 270 $340{ }^{\circ} \mathrm{C}$. The MCM-41 molecular sieve has hexagonally arranged pores, high specific surface area, and large adsorption capacity, which is beneficial in facilitating the synergistic effect between the active component and the support, enhancing the redox property of the active component, and promoting the adsorption and oxidation performances of $\mathrm{C}_{3} \mathrm{H}_{6}$, thereby promoting the production of intermediates (e.g., ONO and $\mathrm{NCO}$ ) and enhancing the catalytic performance of the catalyst. The addition of auxiliaries can further enhance the synergistic effect of the active component and the carrier and promote the adsorption and desorption of NO on the catalyst surface. However, the catalyst with MCM-41 as the carrier has fewer acid sites, lower acid strength, and poor hydrothermal stability, resulting in a maximum NO conversion of less than $80 \%$. When compared with microporous molecular sieve catalysts, the pore size distribution of mesoporous molecular sieve catalysts is relatively uniform and can be controlled; when compared with macroporous molecular sieve catalysts, it has high specific surface area and adsorption capacity. However, the disadvantage of mesoporous molecular sieve catalysts is low hydrothermal stability under current. However, the structure and catalytic performance of the catalysts can be significantly improved by adding additives, modifying the preparation process, and other newer methods. Therefore, the current focus is to investigate mesoporous molecular sieve catalysts with high hydrothermal stability and catalytic performance.

\section{Macroporous zeolite catalysts}

Macroporous molecular sieves have low cost, poor specific surface area, and poor catalytic activity and thermal stability, but a molecular sieve catalyst loaded with noble-metal active components has been widely studied because of its good catalytic performance.

Konsolakis et al. ${ }^{33}$ reported a Pt- $\mathrm{Al}_{2} \mathrm{O}_{3}$ catalyst and a REOmodified $\mathrm{Pt}-\mathrm{Al}_{2} \mathrm{O}_{3}$ catalyst prepared by a coprecipitation method. The study results revealed that as compared to the Pt$\mathrm{Al}_{2} \mathrm{O}_{3}$ catalyst with extremely low catalytic activity, the modified catalyst exhibited good catalytic performance for $\mathrm{C}_{3} \mathrm{H}_{6}$-SCR in the wide temperature range of $320-600{ }^{\circ} \mathrm{C}$. The $\mathrm{N}_{2} \mathrm{O}$ conversion rate exceeded $50 \%$, and the maximum conversion rate was close to $100 \%$ in the temperature range of $450-600{ }^{\circ} \mathrm{C}$. The DRIFTS results obtained using $\mathrm{CO}$ as the probe molecule revealed that the superior catalytic performance of the promoted samples can be mainly attributed to the increase in the available metal surface area and to the development of new Pt sites with exceptional electron density, located on the metal-support interfacial areas.

Moreover, de Lucas-Consuegra et al. ${ }^{34}$ prepared the $\mathrm{Pt}-\mathrm{K}$ $\beta \mathrm{Al}_{2} \mathrm{O}_{3}$ electrochemical catalyst with $\mathrm{K}$ as the promoter by a deposition method. The $\mathrm{C}_{3} \mathrm{H}_{6}$-SCR reaction results revealed that the $\mathrm{N}_{2} \mathrm{O}$ conversion rate exceeded $50 \%$ in the temperature range of $440-580^{\circ} \mathrm{C}$, with the highest being $80 \%$ achieved under the effect of this catalyst. This can be attributed to the interaction between $\mathrm{K}$ and Pt on the catalyst: $\mathrm{K}$ enhanced the catalytic activity of $\mathrm{Pt}$, which improved the catalytic properties of the catalyst and further increased the $\mathrm{N}_{2} \mathrm{O}$ conversion rate. Irani et al. ${ }^{35}$ also found that the $\mathrm{NO}_{2}$ conversion rate exceeded $50 \%$ in the temperature range of $200-350{ }^{\circ} \mathrm{C}$, and it was close to $100 \%$ over the catalyst at $240{ }^{\circ} \mathrm{C}$ on the $\mathrm{Pt}-\mathrm{Pd}-\mathrm{Al}_{2} \mathrm{O}_{3}$ catalyst in the $\mathrm{C}_{3} \mathrm{H}_{6}$-SCR reaction. Here, Pd in the catalyst enhanced the catalytic activity of Pt, and the synergistic action between Pt and Pd favored $\mathrm{NO}_{2}$ reduction within the low-temperature range.

Zhang et al. ${ }^{36}$ prepared the $\mathrm{Ag}-\mathrm{Al}_{2} \mathrm{O}_{3}$ catalyst by the IM method using $\mathrm{AlOOH}$ as the $\mathrm{Al}$ source. The $\mathrm{C}_{3} \mathrm{H}_{6}$-SCR results revealed that the $\mathrm{Ag}-\mathrm{Al}_{2} \mathrm{O}_{3}$ catalyst achieved the best catalytic performance in the temperature range of $300-600{ }^{\circ} \mathrm{C}$, the NO conversion rate exceeded $70 \%$, and the maximum conversion rate was close to $100 \%$ in the temperature range of $350-550{ }^{\circ} \mathrm{C}$. Zhang et al. considered that high-density $\mathrm{Ag}-\mathrm{O}-\mathrm{Al}$ species on the $\mathrm{Ag}-\mathrm{Al}_{2} \mathrm{O}_{3}$ catalyst considerably promoted the selective reduction of $\mathrm{NO}$ to $\mathrm{N}_{2}$. The UV-vis and $\mathrm{H}_{2}$-TPR results indicate that $\mathrm{Ag}^{+}$or $\mathrm{Ag}_{2} \mathrm{O}$ nanoparticles on the catalyst were highly dispersed on the support.

In addition, $\mathrm{Li}$ et $a .^{37}$ investigated the catalytic function of the $\mathrm{Ag}-\mathrm{Al}_{2} \mathrm{O}_{3}$ catalyst assisted by NTP for $\mathrm{C}_{3} \mathrm{H}_{6}$-SCR. The results revealed that the conversion rate of $\mathrm{NO}$ and $\mathrm{NO}_{2}$ exceeded $50 \%$ in the temperature range of $310-550{ }^{\circ} \mathrm{C}$, and the maximum conversion rate of $\mathrm{NO}$ and $\mathrm{NO}_{2}$ reached $90 \%$ in the temperature range of $310-410^{\circ} \mathrm{C}$. The NTP assistance significantly improved the catalytic performance of $\mathrm{Ag}-\mathrm{Al}_{2} \mathrm{O}_{3}$ in the low-temperature range. $\mathrm{Li}$ et al. suggested that NTP assistance promoted the enrichment of intermediates (e.g., $\mathrm{NCO}$ and $\mathrm{CN}$ ), thereby 
increasing the activity of the catalyst and yield of $\mathrm{N}_{2}$ in the $\mathrm{C}_{3} \mathrm{H}_{6}$ SCR reaction. DRIFTS further confirmed that NTP promoted the formation of more nitrogenous organic intermediates, which promoted the formation of more $\mathrm{N}_{2}$ product.

Zhang et al. ${ }^{38}$ found that the catalytic performance of the $\mathrm{Ag}$ $\mathrm{Al}_{2} \mathrm{O}_{3}$ catalyst significantly increased when $\mathrm{H}_{2}$ was introduced into the $\mathrm{C}_{3} \mathrm{H}_{6}$-SCR reaction within a wide temperature range of 210-550 ${ }^{\circ} \mathrm{C}$. The $\mathrm{NO}$ and $\mathrm{NO}_{2}$ conversion rates exceeded $70 \%$, and the conversion temperature was broadened by $190{ }^{\circ} \mathrm{C}$ using a mixture of $\mathrm{H}_{2}$ and $\mathrm{C}_{3} \mathrm{H}_{6}$ rather than pure $\mathrm{C}_{3} \mathrm{H}_{6}$ as the reductant. The DRIFTS results revealed that $\mathrm{H}_{2}$ promoted the formation of -NCO intermediates. The presence of the intermediates allowed $\mathrm{H}_{2}$ to act as a coreducing agent for $\mathrm{C}_{3} \mathrm{H}_{6}$ in order to increase the $\mathrm{NO}$ and $\mathrm{NO}_{2}$ conversion rates.

Moreover, Guo et al. $^{39}$ found that the catalytic performance of the catalyst was significantly increased in a wide temperature range of $300-550{ }^{\circ} \mathrm{C}$ when $1000 \mathrm{ppm} \mathrm{H}_{2}$ was added to the $\mathrm{C}_{3} \mathrm{H}_{6}$ SCR reaction under the effect of the $\mathrm{Ag}-\mathrm{Al}_{2} \mathrm{O}_{3}$ catalyst. The maximum conversion rates of $\mathrm{NO}$ and $\mathrm{NO}_{2}$ reached $95 \%$ when using a mixture of $\mathrm{H}_{2}$ and $\mathrm{C}_{3} \mathrm{H}_{6}$ as the reductant. When the concentration of $\mathrm{H}_{2}$ increased to $5000 \mathrm{ppm}$, the $\mathrm{NO}$ and $\mathrm{NO}_{2}$ conversion rates exceeded $50 \%$, and the conversion temperature was broadened to $75{ }^{\circ} \mathrm{C}$ in the low-temperature range. The NO-TPD results revealed that nitrates were the reactive intermediates in the reaction, and most of the nitrate intermediates adsorbed on the catalyst surface were reduced to $\mathrm{NO}$ and $\mathrm{N}_{2}$ by reaction with $\mathrm{H}_{2}$. Therefore, the presence of $\mathrm{H}_{2}$ considerably promoted the SCR activity of the catalysts.

Pitukmanorom et al. ${ }^{40}$ synthesized $\operatorname{In}_{2} \mathrm{O}_{3}-\mathrm{Ga}_{2} \mathrm{O}_{3}-\mathrm{Al}_{2} \mathrm{O}_{3}$ catalysts with $\mathrm{Ga}$ and In as the active components by the controlled use of chemical precipitation technology. The $\mathrm{C}_{3} \mathrm{H}_{6}$-SCR reaction results revealed that the NO conversion rate exceeded $50 \%$ in the temperature range of $375-550{ }^{\circ} \mathrm{C}$, with the maximum being $80 \%$. This can be attributed to the high surface area of the catalyst and the high dispersibility of the active components ( $\mathrm{Ga}$ and In) on the catalyst surface, while the synergistic effect between $\mathrm{Ga}$ and In promoted the activation of propylene, thereby promoting the formation of the reduction product $\mathrm{N}_{2}$.

Luo et al. ${ }^{41}$ found that the addition of $\mathrm{SO}_{2}$ in the $\mathrm{C}_{3} \mathrm{H}_{6}-\mathrm{SCR}$ reaction enhanced the catalytic performance of the $\operatorname{In}_{2} \mathrm{O}_{3}-\mathrm{Al}_{2} \mathrm{O}_{3}$ catalyst. In the low-temperature range of $200-300{ }^{\circ} \mathrm{C}$, the NO conversion rate under the effect of the catalyst was increased by 15-25\% (as compared to no $\mathrm{SO}_{2}$ ). The DRIFTS results revealed that $\mathrm{SO}_{2}$ promoted the formation of carboxylate and formate species at lower temperatures, thereby promoting the partial oxidation of $\mathrm{C}_{3} \mathrm{H}_{6}$ and promoting the SCR activity.

Liu et al. ${ }^{42}$ prepared $\mathrm{SnO}_{2}-\mathrm{Al}_{2} \mathrm{O}_{3}$ catalysts by $\mathrm{IM}$ and sol-gel (SG) methods. The $\mathrm{C}_{3} \mathrm{H}_{6}$-SCR results revealed that the conversion rates of $\mathrm{NO}$ and $\mathrm{NO}_{2}$ on the catalyst prepared by the SG method exceeded $50 \%$ in the temperature range of $375-510{ }^{\circ} \mathrm{C}$, the maximum being $76 \%$. Within the same temperature range, NO and $\mathrm{NO}_{2}$ conversion rates increased by 13-21\% (when compared with the immersion method). This can be attributed to the more uniform dispersion of $\mathrm{SnO}_{2}$ on the surface of the catalyst prepared by the SG method, which promoted the interaction between the active $\mathrm{SnO}_{2}$ constituent and the $\mathrm{Al}_{2} \mathrm{O}_{3}$ support, thereby improving the catalytic performance of the catalyst.
The XRD results (Fig. 10) further confirmed that the $\mathrm{SnO}_{2}$ species were highly dispersed on the $\mathrm{Al}_{2} \mathrm{O}_{3}$ support. The XPS results also showed that the $\mathrm{Sn}$ on the catalyst prepared by the SG method existed in the form of $\mathrm{Sn}^{4+}$ with a binding energy of $487.2 \mathrm{eV}$. Simultaneously, $\mathrm{Sn}^{4+}$ could interact with $\mathrm{Al}$, which was beneficial toward the reduction of $\mathrm{NO}$ and $\mathrm{NO}_{2}$.

The above studies show that the active components of the catalysts supported by the macroporous molecular sieve $\left(\mathrm{Al}_{2} \mathrm{O}_{3}\right)$ are $\mathrm{Pt}, \mathrm{Ag}$, In, Ga, and $\mathrm{Sn}$ : the preferred active component is $\mathrm{Ag}$. When the noble metal $\mathrm{Ag}$ is used as the active component and $\mathrm{C}_{3} \mathrm{H}_{6}$ is the reducing agent, the operating temperature range is wider than that of nonnoble metal catalysts, but the low-temperature activity of $\mathrm{Ag}-\mathrm{Al}_{2} \mathrm{O}_{3}$ for $\mathrm{NO}_{X}$ reduction by $\mathrm{C}_{3} \mathrm{H}_{6}$ remains to be further explored. Additives (K, Pd, other metals, NTP, other auxiliaries, $\mathrm{H}_{2}$, $\mathrm{SO}_{2}$, etc.) can enhance the synergistic effect between the active components and the carrier and enhance the redox properties of the active components, thereby promoting the redox properties of $\mathrm{C}_{3} \mathrm{H}_{6}$ and further promoting the formation of more reactive intermediates (NCO, CN, carboxylates, formates, etc.). This increases the $\mathrm{NO}_{X}$ conversion rate. For example, $\mathrm{Pd}$ can synergize with $\mathrm{Pt}$ to improve the catalytic performance of $\mathrm{C}_{3} \mathrm{H}_{6}$-SCR in the low-temperature range of $200-350{ }^{\circ} \mathrm{C}$.

The oxygen ions of the $\mathrm{Al}_{2} \mathrm{O}_{3}$ support can be arranged in a hexagonal precision-stacked crystal structure in the preparation process, which does not have a relatively higher specific surface area to provide more active sites, but can enhance the interaction between this carrier and the metal active components dispersed on the surface of the catalyst. This forms the MO-Al species $(\mathrm{M}=\mathrm{Ag}, \mathrm{Pt}$, etc.), which can promote the adsorption and activation of $\mathrm{C}_{3} \mathrm{H}_{6}$ and further promoting the catalytic performance of the catalyst.

In contrast, the macroporous molecular sieve $\left(\mathrm{Al}_{2} \mathrm{O}_{3}\right)$ catalyst has a larger pore size, which is beneficial toward mass transfer and exchange of the reactive molecules. However, its low specific surface area reduces the number of active sites on the catalyst; therefore, the catalytic efficiency of the catalyst is lower than that of mesoporous or microporous molecular sieve catalysts at lower temperatures.

Table 2 summarizes the catalytic temperature ranges and catalytic activities for different molecular sieve de- $\mathrm{NO}_{X}$ catalysts synthesized by using different methods.

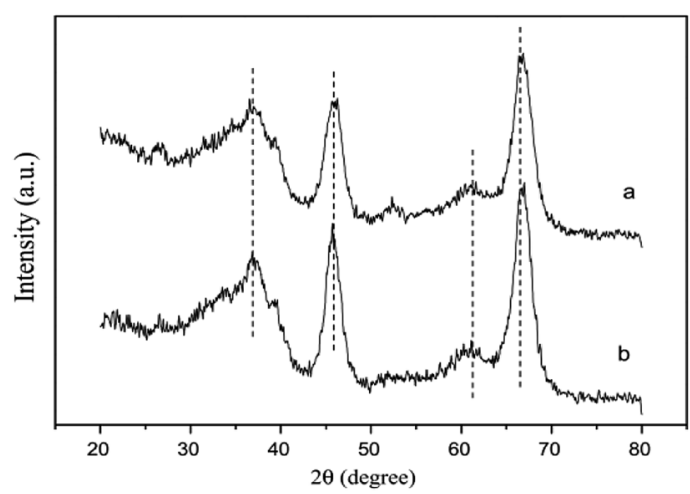

Fig. 10 XRD patterns of two different $\mathrm{SnO}_{2}-\mathrm{Al}_{2} \mathrm{O}_{3}$ catalysts: (a) $\mathrm{Sn}^{5}$ (IM) and (b) $\mathrm{Sn}^{5}$ (SG). ${ }^{42}$ 


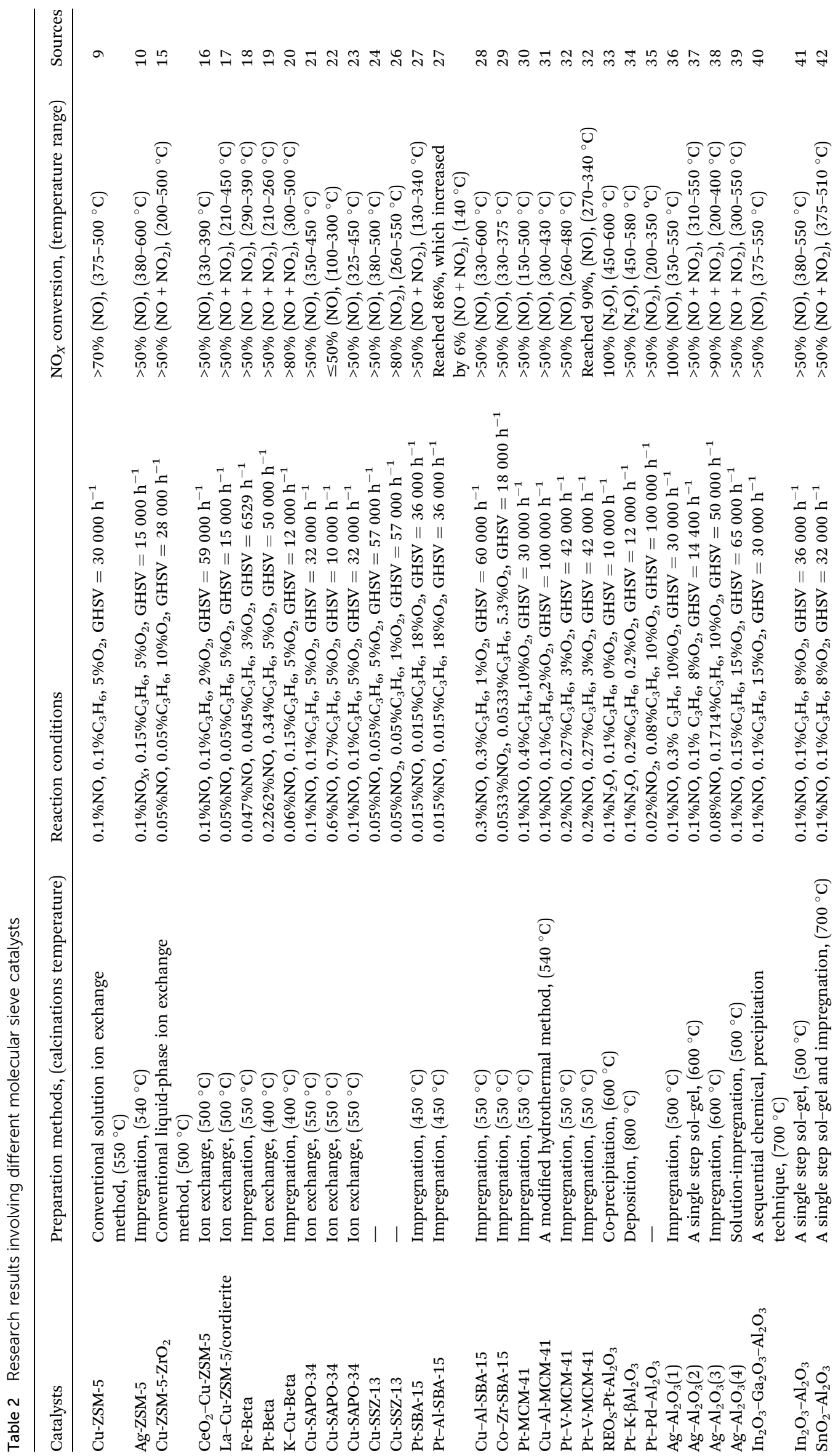


In general, the catalytic function of molecular sieve catalysts is related not only to the active component but also to the structure and texture of the support. Molecular sieves with different pore structures have their own advantages and disadvantages. Microporous molecular sieves have a large specific surface area, high hydrothermal stability, and suitable surface acidity. Nevertheless, the pore structure of microporous molecular sieves is small and complex, which leads to limitations in mass transfer. It is well known that carbon deposition, $\mathrm{SO}_{2}$ poisoning, and dealumination are major causes of catalyst deactivation. Mass transfer restrictions in microporous sieves easily lead to carbon deposition on the surface of the active components by the partial oxidation of hydrocarbons, facilitating the production of sulphites (or sulphates) by the reaction of $\mathrm{SO}_{2}\left(\right.$ or $\left.\mathrm{SO}_{2}+\mathrm{O}_{2}\right)$ and metallic oxides as the active metal component. ${ }^{18}$ Therefore, carbon deposition and $\mathrm{SO}_{2}$ poisoning may be the major causes of deactivation for microporous molecular sieve catalysts.

The macroporous molecular sieve $\left(\mathrm{Al}_{2} \mathrm{O}_{3}\right)$ catalyst has a large pore size, which is beneficial toward mass transfer and exchange of reactive molecules. However, its low specific surface area and nonuniform pore size distribution lowers the catalytic efficiency of the catalyst as compared to that of mesoporous or microporous molecular sieve catalysts at lower temperatures. Table 2 reveals that the macroporous molecular sieve catalyst usually exhibits high activity in the hightemperature region. High-temperature reactions are bound to facilitate the oxidation of hydrocarbons and reaction of both active metal components and $\mathrm{SO}_{2}$, which may be the main cause of catalyst deactivation. Meanwhile, high-temperature water vapor reacts easily with skeletal $\mathrm{Al}$ to form non-skeletal $\mathrm{Al}$ species, $\mathrm{Al}(\mathrm{OH})_{x}$, at higher temperatures, yielding structural changes in macroporous molecular sieves and reducing hydrothermal stability and catalytic activity of the catalysts.

When compared with microporous and macroporous molecular sieve catalysts, mesoporous molecular sieves have a higher specific surface area, cation exchange, and hydrocarbon-sorption capacities, and the pore size distribution of mesoporous molecular sieve catalysts is relatively uniform and can be controlled. Table 2 shows that some catalysts such as Pt-V-MCM-41, Pt-MCM-41, and Pt-SBA-15 exhibited good catalytic activity at low temperatures (lower than $300{ }^{\circ} \mathrm{C}$ ). The low reaction temperature and rapid mass transfer in mesoporous supports can reduce carbon deposition and sulphites (or sulphates), and therefore, reduce the probability of catalyst deactivation. Further, the high specific surface of mesoporous supports is beneficial in increasing the degree of dispersion of the active metal components and the number of active sites on the catalyst surface. This facilitates the increase in the catalytic activity. However, the disadvantage of mesoporous molecular sieve catalysts is low hydrothermal stability under current. Therefore, the thermal and hydrothermal stabilities of these mesoporous materials are crucial factors in their potential applications. As a result of the hydrolysis of bare $\mathrm{Si}-\mathrm{O}-\mathrm{Si}$ bonds in the presence of absorbed water, mesoporous silicate zeolites can lose their structure when exposed to high-temperature steam and boiling water for a long period of time. In order to improve the thermal and hydrothermal stabilities of mesoporous molecular sieve catalyst materials, many approaches have been investigated.

\section{$5 \mathrm{C}_{3} \mathrm{H}_{6}-\mathrm{SCR}$ mechanisms under molecular sieve catalysts}

The study of the catalytic reaction mechanism is an important aspect of catalyst research. Since the reaction pathway of the $\mathrm{C}_{3} \mathrm{H}_{6}$-SCR reaction over molecular sieve catalysts is very complicated and the type of molecular sieve catalyst is a major factor affecting the reaction pathway, there are different viewpoints on the mechanism of $\mathrm{C}_{3} \mathrm{H}_{6}$-SCR under the action of different molecular sieve catalysts. Therefore, numerous researchers have proposed different reaction pathways for $\mathrm{C}_{3} \mathrm{H}_{6}$-SCR in the presence of different molecular sieve catalysts. ${ }^{43-54}$

Li et al. ${ }^{43}$ considered that propylene may serve as a $\mathrm{NO}_{X}$ reductant according to the reaction on Fe-ZSN-5 and Cu-SSZ-13 zeolite catalysts:

$$
\mathrm{C}_{3} \mathrm{H}_{6}+\mathrm{NO}+4 \mathrm{O}_{2} \rightarrow 0.5 \mathrm{~N}_{2}+3 \mathrm{H}_{2} \mathrm{O}+3 \mathrm{CO}_{2}
$$

However, Kotsifa et al. $^{44}$ proposed that in the presence of oxygen in the feed, $\mathrm{Pt}-\mathrm{Al}_{2} \mathrm{O}_{3}$ promoted the $\mathrm{C}_{3} \mathrm{H}_{6}$-SCR reaction of $\mathrm{NO}$ according to the following overall stoichiometric reactions:

$$
\begin{gathered}
\mathrm{C}_{3} \mathrm{H}_{6}+2 \mathrm{NO}+(7 / 2) \mathrm{O}_{2} \rightarrow \mathrm{N}_{2}+3 \mathrm{H}_{2} \mathrm{O}+3 \mathrm{CO}_{2} \\
\mathrm{C}_{3} \mathrm{H}_{6}+2 \mathrm{NO}+4 \mathrm{O}_{2} \rightarrow \mathrm{N}_{2} \mathrm{O}+3 \mathrm{H}_{2} \mathrm{O}+3 \mathrm{CO}_{2}
\end{gathered}
$$

Similarly, Vaccaro et $a l .^{45}$ reported that the oxidation of propylene (eqn (4)) was one of the two main reactions taking place in the $\mathrm{C}_{3} \mathrm{H}_{6}-\mathrm{SCR}$ process over a $\mathrm{Pt}-\mathrm{Al}_{2} \mathrm{O}_{3}$ catalyst. The other was the reduction of $\mathrm{NO}$ (eqn (5), with $n$ being an integer, $0<n<9$ ).

$$
2 \mathrm{C}_{3} \mathrm{H}_{6}+9 \mathrm{O}_{2} \rightarrow 6 \mathrm{H}_{2} \mathrm{O}+6 \mathrm{CO}_{2}
$$

$2 \mathrm{C}_{3} \mathrm{H}_{6}+(18+2 n) \mathrm{NO} \rightarrow 2 n \mathrm{~N}_{2} \mathrm{O}+6 \mathrm{H}_{2} \mathrm{O}+6 \mathrm{CO}_{2}+(9-n) \mathrm{N}_{2}(5)$

Rosas et al. ${ }^{46}$ combined the two main reaction pathways to describe NO reduction over a Pt-SiO${ }_{2}$ catalyst in the presence of propylene and oxygen. The first one was the production of molecular nitrogen through NO dissociative adsorption via the redox pathway. The other was the activated propylene reacting with $\mathrm{NO}$ to finally decompose into $\mathrm{N}_{2}$. Based on the above results, the following reaction pathways were proposed for the low-temperature SCR:

$$
\begin{gathered}
*+* \mathrm{NO} \leftrightarrow * \mathrm{~N}+* \mathrm{O} \\
*+\mathrm{C}_{3} \mathrm{H}_{6} \leftrightarrow{ }^{*} \mathrm{C}_{3} \mathrm{H}_{6} \\
{ }^{*} \mathrm{C}_{3} \mathrm{H}_{6}+* \mathrm{O} \rightarrow{ }^{*} \mathrm{C}_{3} \mathrm{H}_{6} \mathrm{O}+* \\
{ }^{*} \mathrm{C}_{3} \mathrm{H}_{6}+4 \mathrm{O}_{2} \rightarrow 3 \mathrm{CO}_{2}+3 \mathrm{H}_{2} \mathrm{O}+*
\end{gathered}
$$




$$
\begin{gathered}
* \mathrm{~N}+* \mathrm{~N} \rightarrow \mathrm{N}_{2}+2 * \\
* \mathrm{C}_{3} \mathrm{H}_{6} \mathrm{O}+* \mathrm{NO} \rightarrow * \mathrm{C}_{3} \mathrm{H}_{6} \mathrm{NO}_{2}+* \\
* \mathrm{C}_{3} \mathrm{H}_{6} \mathrm{NO}_{2}+* \mathrm{NO}+3 \mathrm{O}_{2} \rightarrow \mathrm{N}_{2}+3 \mathrm{CO}_{2}+3 \mathrm{H}_{2} \mathrm{O}+2 *
\end{gathered}
$$

$\mathrm{C}_{3} \mathrm{H}_{6}$, NO, and $\mathrm{O}_{2}$ are considered to be adsorbed on the same type of Pt adsorption sites (denoted as *).

Furthermore, He et $a .^{47}$ reported two attractive reaction pathways for the SCR of $\mathrm{NO}$ by $\mathrm{C}_{3} \mathrm{H}_{6}$ over $\mathrm{Ag}-\mathrm{Al}_{2} \mathrm{O}_{3}$ and $\mathrm{Cu}-$ $\mathrm{Al}_{2} \mathrm{O}_{3}$ catalysts. The main reaction pathway over the $\mathrm{Ag}-\mathrm{Al}_{2} \mathrm{O}_{3}$ catalyst can be summarized as follows:

$$
\begin{gathered}
\mathrm{NO}+\mathrm{C}_{3} \mathrm{H}_{6}+\mathrm{O}_{2} \rightarrow \begin{array}{c}
\mathrm{CH}_{3} \mathrm{COO}^{-}+\mathrm{RCH}=\mathrm{CH}-\mathrm{O}^{-} \\
+
\end{array} \\
\mathrm{NO}_{2}\left(\mathrm{NO}_{3}{ }^{-}\right) \\
\mathrm{CH}_{3} \mathrm{COO}^{-}+\mathrm{RCH}=\mathrm{CH}-\mathrm{O}^{-}+\mathrm{NO}_{2}\left(\mathrm{NO}_{3}{ }^{-}\right) \rightarrow \begin{array}{r}
\mathrm{R}-\mathrm{NO}_{2} \\
+\mathrm{R}-\mathrm{ONO}
\end{array} \\
\mathrm{R}-\mathrm{NO}_{2}+\mathrm{R}-\mathrm{ONO} \rightarrow \mathrm{NCO}+\mathrm{NO}+\mathrm{O}_{2} \\
\mathrm{NCO}+\mathrm{NO}+\mathrm{O}_{2} \rightarrow \mathrm{N}_{2}+\mathrm{CO}_{2}
\end{gathered}
$$

The main reaction pathway over the $\mathrm{Cu}-\mathrm{Al}_{2} \mathrm{O}_{3}$ catalyst can be summarized as follows:

$$
\begin{aligned}
& \mathrm{NO}+\mathrm{C}_{3} \mathrm{H}_{6}+\mathrm{O}_{2} \rightarrow \mathrm{CH}_{3} \mathrm{COO}^{-}+\mathrm{NO}_{2}\left(\mathrm{NO}_{3}{ }^{-}\right) \\
& \mathrm{CH}_{3} \mathrm{COO}^{-}+\mathrm{NO}_{2}\left(\mathrm{NO}_{3}{ }^{-}\right) \rightarrow \mathrm{NO}+\mathrm{H}_{2} \mathrm{O}+\mathrm{CO}_{2}
\end{aligned}
$$

Similarly, Wang et $a .^{48}$ also summarized and proposed an attractive reaction pathway of the SCR of NO by $\mathrm{C}_{3} \mathrm{H}_{6}$ over Pd$\mathrm{Al}_{2} \mathrm{O}_{3}$.

$$
\begin{gathered}
\mathrm{NO}+\mathrm{C}_{3} \mathrm{H}_{6}+\mathrm{O}_{2} \rightarrow \mathrm{NO}_{X}(\text { nitrate })+\mathrm{C}_{x} \mathrm{H}_{y} \mathrm{O}_{z} \\
\mathrm{NO}_{X}(\text { nitrate })+\mathrm{C}_{x} \mathrm{H}_{y} \mathrm{O}_{z} \rightarrow \mathrm{R}-\mathrm{NO}_{2}+\mathrm{R}-\mathrm{ONO} \\
\mathrm{R}-\mathrm{NO}_{2}+\mathrm{R}-\mathrm{ONO} \rightarrow-\mathrm{NCO}+-\mathrm{CN} \\
-\mathrm{NCO}+\mathrm{NO}+\mathrm{O}_{2} \rightarrow \mathrm{N}_{2}
\end{gathered}
$$

$\mathrm{NO}, \mathrm{O}_{2}$, and $\mathrm{C}_{3} \mathrm{H}_{6}$ were first adsorbed on the catalyst carrier $\mathrm{Al}_{2} \mathrm{O}_{3}$. Then, the NO part reacted with oxygen to form nitrogen oxides, such as $\mathrm{NO}_{X}$ and nitrate species. Further, $\mathrm{C}_{3} \mathrm{H}_{6}$ combined with oxygen to form the corresponding carbon hydroxides, as shown in eqn (19). Then, the active intermediates, $\mathrm{R}-\mathrm{NO}_{2}$ and $\mathrm{R}-\mathrm{ONO}$, were formed by the catalysis of $\mathrm{NO}_{X}$ and carbon hydroxides with $\mathrm{Pd}$, as shown in eqn (20). The active intermediates could be easily transformed into a -NCO species by eqn (21), and -NCO was an active species of NO selective catalytic reduction to $\mathrm{N}_{2}$ and reacting with $\mathrm{NO}$ and $\mathrm{O}_{2}$ to generate $\mathrm{N}_{2}$ by eqn (22). In other words, $\mathrm{C}_{3} \mathrm{H}_{6}$ adsorption on the catalyst surface is required for the SCR reactions to proceed.

In addition, Capek et al. ${ }^{55}$ proposed that $\mathrm{R}-\mathrm{NO}_{X}$ was the main intermediate when the Cu-ZSM-5 zeolite catalyst was used. Sobczak et al. ${ }^{56}$ and Goscianska et al. ${ }^{57}$ found that $-\mathrm{N}_{2} \mathrm{O}(\mathrm{g})$ and -NCO were important organic nitrogenous intermediates when the Nb-MCM-41 molecular sieve catalyst was used. Shimizu et $a l .{ }^{58}$ also found that intermediates such as $-\mathrm{NCO}$ and $-\mathrm{CN}$ were the major intermediates when $\mathrm{Cu}-\mathrm{Al}_{2} \mathrm{O}_{3}$ molecular sieve catalysts were used.

At present, a more consistent view is that the mechanism of catalysis and reduction of $\mathrm{NO}_{X}$ under the $\mathrm{C}_{3} \mathrm{H}_{6}$-SCR system belongs to a redox-type mechanism. ${ }^{59-107}$ The reaction process (Fig. 11) includes three steps. First, $\mathrm{NO}$ is oxidized into $\mathrm{NO}_{2}$ and $\mathrm{NO}_{X}$ (ads) or nitrate species on the surface of the catalyst, and the reducing agent is partially oxidized to $\mathrm{C}_{x} \mathrm{H}_{y} \mathrm{O}_{z}$ (ads) or acetate species. The second is the formation of nitrogencontaining organic intermediates. $\mathrm{C}_{x} \mathrm{H}_{y} \mathrm{O}_{z}$ (ads) reacts with $\mathrm{NO}_{X}$ (ads) to form nitrogen-containing organic intermediates $\left(\mathrm{R}-\mathrm{NO}_{2}, \mathrm{R}-\mathrm{ONO}\right)$, and the intermediates are rapidly converted into $\mathrm{R}-\mathrm{CN}, \mathrm{R}-\mathrm{NCO}, \mathrm{R}-\mathrm{NH}_{2}$, and other species on the surface of the catalyst. Finally, organic intermediates (e.g., R-CN) react with $\mathrm{NO}+\mathrm{O}_{2}$ to produce the final product $\mathrm{N}_{2}$.

Most of the reaction mechanisms reported in the above literature assume that the reaction intermediate is the key to the catalytic reaction. Therefore, on the basis of the above literature and the structure and characteristics of different supported types of molecular sieve catalysts, we suggest that the mechanism of $\mathrm{C}_{3} \mathrm{H}_{6}$-SCR under the action of molecular sieve catalysts is as follows: (i) $\mathrm{C}_{3} \mathrm{H}_{6}$ is oxidized into $\mathrm{C}_{x} \mathrm{H}_{y} \mathrm{O}_{z}$ (ads) or acetate species on the catalyst surface, and $\mathrm{NO}$ is oxidized into $\mathrm{NO}_{2}$ in an oxygen-rich atmosphere; (ii) $\mathrm{C}_{x} \mathrm{H}_{y} \mathrm{O}_{z}$ (ads) reacts with $\mathrm{NO}_{2}$ to produce the nitrogen-containing organic intermediate $\mathrm{R}-\mathrm{NCO}$; and (iii) the organic intermediate, R-NCO, reacts with $\mathrm{NO}_{2}+\mathrm{O}_{2}$, yielding the final product $\mathrm{N}_{2}$.

\section{Design strategies for supported molecular sieve catalysts}

The design of supported molecular sieve catalysts should not only consider the high activity of the catalyst, but also the high stability of the catalyst. From the results of current research, it is evident that the properties of the catalyst are related to the selection of active components, promoter, supports, and so on, and it is necessary to obtain a low-temperature catalyst with high activity to avoid the deactivation of the catalyst at high reaction temperatures.

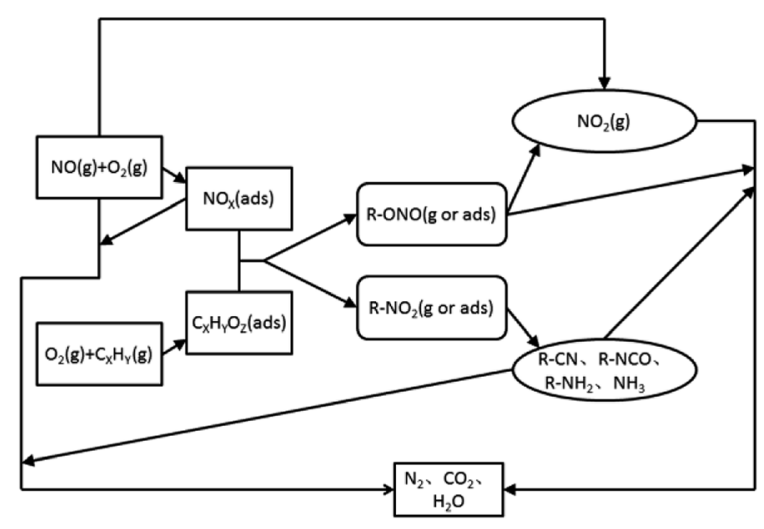

Fig. $11 \mathrm{HC}-\mathrm{SCR}$ redox mechanism schematic. 
From Table 2, it is evident that Pt and some transition metals are usually selected as the active components of supported molecular sieve catalysts. Pt (Pt-SBA-15), La (La-Cu-ZSM-5/ cordierite), $\mathrm{Ag}\left(\mathrm{Ag}-\mathrm{Al}_{2} \mathrm{O}_{3}(3)\right)$, and $\mathrm{Cu}$ (Cu-SAPO-34) catalysts exhibit good low-temperature catalytic activity (Table 2). Therefore, these four metals can be used as the first choice of active components in the design of supported molecular sieve catalysts. However, considering the cost factor, the selection of the transition metal as the active component necessitates a higher performance-to-cost ratio. Further, the reaction of silver with sulfur dioxide is difficult, which can deter $\mathrm{SO}_{2}$ poisoning in the catalyst. The combination of transition metals as the active component and lanthanide elements as the promoter usually exhibits high activity at low temperatures in the catalysts; therefore, this combination deserves further consideration in the design of supported molecular sieve catalysts.

Studies have shown that the addition of a promoter in the catalyst can improve the low-temperature activity and stability of the catalyst due to the synergistic effect between the assistant and active components. For instance, the $\mathrm{NO}_{X}$ conversion rate is close to $100 \%$ over the $\mathrm{Pt}-\mathrm{Pd}-\mathrm{Al}_{2} \mathrm{O}_{3}$ catalyst at $240{ }^{\circ} \mathrm{C}$ in the $\mathrm{C}_{3} \mathrm{H}_{6}$-SCR reaction; ${ }^{35}$ the catalytic efficiency is considerably improved due to the synergistic action of Pd at lower temperatures. Kucherov et al. ${ }^{\mathbf{1 0 8}}$ also found that the introduction of lanthanides in Cu-HZSM-5 can improve, to some extent, the catalyst resistance against high-temperature deactivation. Therefore, the selection of proper additives is necessary in the design of catalysts. The auxiliaries of the catalysts in Table 2 (for example, $\mathrm{Pd}, \mathrm{Al}, \mathrm{V}$, etc.) are worthwhile in the design strategies of supported molecular sieve catalysts.

Based on the previous analysis of the structural characteristics of molecular sieves with different pore sizes, we believe that mesoporous molecules can be used as the preferred support for low-temperature active catalysts. The high specific surface of mesoporous molecular sieves can improve the dispersity of the active component and the number of active sites on the catalyst, thereby increasing the activity of the catalyst. Furthermore, uniformity in the carrier pore size is beneficial toward higher distribution of active components, and high $\mathrm{C}_{3} \mathrm{H}_{6}$-sorption capacities facilitate $\mathrm{C}_{3} \mathrm{H}_{6}$-SCR. Improvements in the hydrothermal stability of mesoporous molecular sieves is the current focus. Introducing additives in mesoporous molecular sieves is an effective way to achieve stability improvement. Another route for improving the hydrothermal stability is to thicken the pore walls of mesoporous molecular sieves by altering the synthesis conditions (such as changing acid or basic conditions, templating agent, temperature, and reaction time). The recent discovery that inorganic silicates and organic surfactant precursors can self-organize to form ordered materials with nanometer-scale periodicities has created exciting avenues for the synthesis of high hydrothermally stable mesoporous materials.

\section{Conclusion}

Supported molecular sieve catalysts exhibit wide catalytic temperature windows, and some catalysts such as $\mathrm{K}-\mathrm{Cu}-\mathrm{Beta}$,
$\mathrm{Cu}-\mathrm{SAPO}-34$, and $\mathrm{Ag}-\mathrm{Al}_{2} \mathrm{O}_{3}(3)$ (Table 2) exhibit lowtemperature catalytic activity. Changes in the synthesis methods can change the structures and textures of the catalysts, such as the number of active sites, pore diameter, and specific area, as well as the dispersion of active components, consequently improving the catalytic function of the catalysts.

The choice of the supported metal as the active constituent is very important for the catalytic function of the catalysts. Studies have shown that $\mathrm{Pt}, \mathrm{Ag}$, and $\mathrm{Cu}$ are usually selected as the active components of different load types of molecular sieve catalysts, and some catalysts exhibit good catalytic performance and wide operating temperatures in the $\mathrm{C}_{3} \mathrm{H}_{6}$-SCR reaction; the synergistic effect of multi-metals such as $\mathrm{Pt}$ and $\mathrm{Pd}$ in the Pt-Pd$\mathrm{Al}_{2} \mathrm{O}_{3}$ catalyst is beneficial toward improving the lowtemperature activity of the catalyst. The $\mathrm{NO}_{X}$ conversion rate was close to $100 \%$ over the catalyst at $240{ }^{\circ} \mathrm{C}$ on the catalyst in the $\mathrm{C}_{3} \mathrm{H}_{6}$-SCR reaction. NTP assistance can promote the enrichment of intermediates such as NCO and $\mathrm{CN}$ in the catalytic reaction. Further, $\mathrm{H}_{2}$ in the mixture of $\mathrm{H}_{2}$ and $\mathrm{C}_{3} \mathrm{H}_{6}$ as the reductant can promote the formation of - $\mathrm{NCO}$ intermediates, thereby improving the low-temperature activity of the catalyst.

Despite considerable progresses made in the studies involving supported molecular sieve catalysts, some issues need to be investigated further in order to accurately construct supported molecular sieve catalysts for high catalytic activity and wide operating temperatures in the $\mathrm{C}_{3} \mathrm{H}_{6}$-SCR reaction. (1) The extraordinary catalytic efficiency of multi-metals generally relies on the cooperative action between the multi-metals and multisupports; therefore, cooperative catalysis is an important factor to be considered in the design of supported molecular sieve catalysts. (2) The synergistic mechanism between the active components and assistants/supports for supported molecular sieve catalysts is not very clear; therefore, it needs to be exhaustively investigated. (3) The catalytic mechanisms of supported molecular sieve catalysts are associated with many factors. In order to elucidate the catalytic mechanisms of the catalyst, it is necessary to further investigate the relationship between the catalytic efficiency and catalyst structure/ component, such as pore diameter and surface area of molecular sieves, dispersion of metal active components of the catalysts, and so on. Perhaps, the most intriguing aspect for studies involving catalytic mechanisms is to determine the structure of intermediate species in the $\mathrm{C}_{3} \mathrm{H}_{6}$-SCR reaction by using modern instrumental analysis methods. (4) Enhancements in the lowtemperature activity and extending the operating temperatures by introducing other assistive methods and mixing reductants in the $\mathrm{C}_{3} \mathrm{H}_{6}$-SCR reaction are worth exploring further.

\section{Conflicts of interest}

Authors declare no conflict of interest.

\section{Acknowledgements}

This work was supported by the National Natural Science Foundation of China (21206202), the Key Industries Common 
Key Technology Innovation Special of Chongqing City, China (cstc2016zdcy-ztzx0020-02), the Science and Technology Plan Project of Sichuan Province, China (2017GZ0421), Banan Science and Technology Foundation of Chongqing (No. 2017TJ10, 2018TJ03), the Excellent Talent Program for the Fifth Batch of Universities in Chongqing, China (2017-28), Graduate Scientific Research Innovation Project of Chongqing (CYS18314).

\section{References}

1 S. A. Yashnik, A. V. Salnikov, N. T. Vasenin, V. F. Anufrienko and Z. R. Ismagilov, Catal. Today, 2012, 197, 214-227.

2 A. V. Boix, S. G. Aspromonte and E. E. Miró, Appl. Catal., A, 2008, 341, 26-34.

3 G. Li, X. Wang, C. Jia and Z. Liu, J. Catal., 2008, 257, 291296.

4 F. Lónyi, H. E. Solt, J. Valyon, A. Boix and L. B. Gutierrez, Appl. Catal., B, 2012, 117, 212-223.

5 V. Rico-Pérez, J. M. García-Cortés, C. S. M. De Lecea and A. Bueno-López, Chem. Eng. Sci., 2013, 104, 557-564.

6 A. N. Mendes, A. Matynia, A. Toullec, S. Capela, M. F. Ribeiro, C. Henriques and P. Da Costa, Appl. Catal., A, 2015, 506, 246-253.

7 M. Iwamoto, H. Yahiro, S. Shundo, Y. Yu-u and N. Mizuno, Appl. Catal., 1991, 69, L15-L19.

8 W. Held, A. Koenig, T. Richter and L. Puppe, SAE Trans., 1990, 209-216.

9 L. Li and N. Guan, Microporous Mesoporous Mater., 2009, 117, 450-457.

10 F. Schuricht and W. Reschetilowski, Microporous Mesoporous Mater., 2012, 164, 135-144.

11 W. Shan and H. Song, Catal. Sci. Technol., 2015, 5, 42804288.

12 R. M. Heck, Catal. Today, 1999, 53, 519-523.

13 L. Lietti, G. Ramis and F. Berti, Appl. Catal., B, 1998, 18, 136.

14 Z. Liu and S. Ihl Woo, Catal. Rev., 2006, 48, 43-89.

15 C. K. Seo, B. Choi, H. Kim, C. H. Lee and C. B. Lee, Chem. Eng. J., 2012, 191, 331-340.

16 V. G. Komvokis, E. F. Iliopoulou, I. A. Vasalos, K. S. Triantafyllidis and C. L. Marshall, Appl. Catal., A, 2007, 325, 345-352.

17 T. Wang, L. Li and N. Guan, Fuel Process. Technol., 2013, 108, 41-46.

18 H. Pan, Y. Guo and H. T. Bi, Chem. Eng. J., 2015, 280, 66-73. 19 J. G. Cortés, M. I. Gómez and C. S. M. de Lecea, Appl. Catal., $B, 2007,74,313-323$.

20 N. Nejar and M. J. Illán-Gómez, Catal. Today, 2007, 119, 262-266.

21 X. G. Li, H. Z. Yan, J. L. Lv, L. Bo and F. M. Jin, Chem. Ind. Eng., 2017, 34, 8-12.

22 Y. Q. Zuo, L. N. Han, W. R. Bao, L. P. Chang and J. C. Wang, Chin. J. Catal., 2013, 34, 1112-1122.

$23 \mathrm{~J} . \mathrm{L} . \mathrm{Lv}$, The preparation of the Cu-SAPO-34 catalyst and its $\mathrm{C}_{3} \mathrm{H}_{6}-\mathrm{SCR}$ performance, Tianjin University, Tianjin City, China, 2014.
24 R. Raj, M. P. Harold and V. Balakotaiah, Chem. Eng. J., 2014, 254, 452-462.

25 D. J. Kim, J. Wang and M. Crocker, Catal. Today, 2014, 231, 83-89.

26 R. Raj, M. P. Harold and V. Balakotaiah, Ind. Eng. Chem. Res., 2013, 52, 15455-15465.

27 X. Liu, Z. Jiang, M. Chen, J. Shi, W. Shangguan and Y. Teraoka, J. Environ. Sci., 2013, 25, 1023-1033.

28 R. Zhang, D. Shi, Y. Zhao, B. Chen, J. Xue, X. Liang and Z. Lei, Catal. Today, 2011, 175, 26-33.

29 A. Sabbaghi, F. L. Y. Lam and X. Hu, Mol. Catal., 2017, 440, 1-8.

30 D. J. Kim, J. W. Kim, S. J. Choung and M. Kang, J. Ind. Eng. Chem., 2008, 14, 308-314.

31 Y. Wan, J. Ma, Z. Wang, W. Zhou and S. Kaliaguine, J. Catal., 2004, 227, 242-252.

32 J. Y. Jeon, H. Y. Kim and S. I. Woo, Appl. Catal., B, 2003, 44, 301-310.

33 M. Konsolakis, C. Drosou and I. V. Yentekakis, Appl. Catal., $B, 2012,123,405-413$.

34 A. de Lucas-Consuegra, F. Dorado, C. Jiménez-Borja and J. L. Valverde, Appl. Catal., B, 2008, 78, 222-231.

35 K. Irani, W. S. Epling and R. Blint, Appl. Catal., B, 2009, 92, 422-428.

36 R. Zhang and S. Kaliaguine, Appl. Catal., B, 2008, 78, 275287.

37 J. Li, R. Ke, W. Li and J. Hao, Catal. Today, 2007, 126, 272278.

38 X. Zhang, Y. Yu and H. He, Appl. Catal., B, 2007, 76, 241247.

39 Y. Guo, J. Chen and H. Kameyama, Appl. Catal., A, 2011, 397, 163-170.

40 P. Pitukmanorom and J. Y. Ying, Nano Today, 2009, 4, 220226.

41 C. Luo, J. Li, Y. Zhu and J. Hao, Catal. Today, 2007, 119, 4851.

42 Z. Liu, J. Li and J. Hao, Chem. Eng. J., 2010, 165, 420-425.

43 M. Li, V. G. Easterling and M. P. Harold, Appl. Catal., B, 2016, 184, 364-380.

44 A. Kotsifa, D. I. Kondarides and X. E. Verykios, Appl. Catal., B, 2008, 80, 260-270.

45 A. R. Vaccaro, G. Mul, J. Pérez-Ramırez, et al.,, Appl. Catal., $B, 2003,46,687-702$.

46 J. M. Rosas, R. Ruiz-Rosas, J. Rodríguez-Mirasol, et al.,, Chem. Eng. J., 2017, 327, 351-360.

47 H. He, C. B. Zhang and Y. B. Yu, Catal. Today, 2004, 90, 191197.

48 Y. D. Wang, H. J. Zhang and D. N. He, J. Inorg. Mater., 2011, 26, 311-316.

49 N. Jagtap, S. B. Umbarkar, P. Miquel, et al.,, Appl. Catal., B, 2009, 90, 416-425.

50 J. Wang, Y. Ji, Z. He, et al., Appl. Catal., B, 2012, 111, 562570.

51 P. Denton, A. Giroir-Fendler, Y. Schuurman, et al., Appl. Catal., A, 2001, 220, 141-152.

52 A. Bueno-Lopez, M. J. Illan-Gomez and C. S. M. de Lecea, Appl. Catal., A, 2006, 302, 244-249. 
53 J. Long, Z. Zhang, Z. Ding, et al.,,J. Phys. Chem. C, 2010, 114, 15713-15727.

54 M. Li, V. G. Easterling and M. P. Harold, Catal. Today, 2016, 267, 177-191.

55 L. Čapek, K. Novoveska, Z. Sobalik, B. Wichterlová, L. Cider and E. Jobson, Appl. Catal., B, 2005, 60, 201-210.

56 I. Sobczak, M. Ziolek and M. Nowacka, Microporous Mesoporous Mater., 2005, 78, 103-116.

57 J. Goscianska, P. Bazin, O. Marie, M. Daturi, I. Sobczak and M. Ziolek, Catal. Today, 2007, 119, 78-82.

58 K. I. Shimizu, H. Kawabata, H. Maeshima, A. Satsuma and T. Hattori, J. Phys. Chem. B, 2000, 104, 2885-2893.

59 S. Chansai, R. Burch, C. Hardacre, J. Breen and F. Meunier, J. Catal., 2011, 281, 98-105.

60 Y. P. Chen, D. G. Cheng, F. Q. Chen and Y. L. Zhan, Progress in Chemistry, 2014, 26, 248-258.

61 R. Brosius and J. A. Martens, Top. Catal., 2004, 28, 119-130.

62 G. Delahay, A. Guzmán-Vargas and B. Coq, Appl. Catal., B, 2007, 70, 45-52.

63 R. Matarrese, H. H. Ingelsten and M. Skoglundh, J. Catal., 2008, 258, 386-392.

64 N. W. Cant and I. O. Liu, Catal. Today, 2000, 63, 133-146.

65 I. Sobczak, K. Musialska, H. Pawlowski and M. Ziolek, Catal. Today, 2011, 176, 393-398.

66 H. H. Ingelsten, A. Palmqvist and M. Skoglundh, J. Phys. Chem. B, 2006, 110, 18392-18400.

67 P. Pietrzyk, C. Dujardin, K. Góra-Marek, P. Granger and Z. Sojka, Phys. Chem. Chem. Phys., 2012, 14, 2203-2215.

68 S. K. Park, Y. K. Park, S. E. Park and L. Kevan, Phys. Chem. Chem. Phys., 2000, 2, 5500-5509.

69 I. Sobczak, A. Kusior and M. Ziolek, Catal. Today, 2008, 137, 203-208.

70 M. Misono, H. Niiro and Y. Hirao, Res. Chem. Intermed., 1998, 24, 123-132.

71 O. Gorce, F. Baudin, C. Thomas, P. Da Costa and G. DjégaMariadassou, Appl. Catal., B, 2004, 54, 69-84.

72 R. Burch and J. A. Sullivan, J. Catal., 1999, 182, 489-496.

73 R. Burch, A. A. Shestov and J. A. Sullivan, J. Catal., 1999, 182, 497-506.

74 G. Xu, J. Ma, G. He, Y. Yu and H. He, Appl. Catal., B, 2017, 207, 60-71.

75 T. Gerlach and M. Baerns, Chem. Eng. Sci., 1999, 54, 43794384.

76 G. Li, S. C. Larsen and V. H. Grassian, J. Mol. Catal. A: Chem., 2005, 227, 25-35.

77 J. H. Jang, S. C. Lee, D. J. Kim, M. Kang and S. J. Choung, Appl. Catal., A, 2005, 286, 36-43.

78 T. Furusawa, L. Lefferts, K. Seshan and K. I. Aika, Appl. Catal., B, 2003, 42, 25-34.

79 A. W. L. Ting, M. P. Harold and V. Balakotaiah, Chem. Eng. Sci., 2018.

80 D. K. Captain and M. D. Amiridis, J. Catal., 1999, 184, 377389.
81 R. Q. Long and R. T. Yang, J. Phys. Chem. B, 1999, 103, 22322238.

82 V. A. Bell, J. S. Feeley, M. Deeba and R. J. Farrauto, Catal. Lett., 1994, 29, 15-26.

83 H. Yasuda, T. Miyamoto and M. Misono, Reduction of Nitrogen Oxide Emissions, 1995, vol. 587, pp. 110-122.

84 K. L. Roberts and M. D. Amiridis, Ind. Eng. Chem. Res., 1997, 36, 3528-3532.

85 S. C. Shen and S. Kawi, Catal. Today, 2001, 68, 245-254.

86 P. A. Kumar, M. P. Reddy, L. K. Ju, B. Hyun-Sook and H. H. Phil, J. Mol. Catal. A: Chem., 2008, 291, 66-74.

87 A. Obuchi, A. Ogata, K. Mizuno, A. Ohi, M. Nakamura and H. Ohuchi, J. Chem. Soc., Chem. Commun., 1992, 247-248.

88 S. C. Shen and S. Kawi, J. Catal., 2003, 213, 241-250.

89 G. P. Ansell, A. F. Diwell, S. E. Golunski, J. W. Hayes, R. R. Rajaram, T. J. Truex and A. P. Walker, Appl. Catal., B, 1993, 2, 81-100.

90 R. Burch, P. J. Millington and A. P. Walker, Appl. Catal., B, 1994, 4, 65-94.

91 A. P. Walker, Catal. Today, 1995, 26, 107-128.

92 J. A. Martens, A. Cauvel, A. Francis, C. Hermans, F. Jayat, M. Remy and P. A. Jacobs, Angew. Chem., Int. Ed., 1998, 37, 1901-1903.

93 S. Tamm, H. H. Ingelsten and A. E. Palmqvist, J. Catal., 2008, 255, 304-312.

94 Y. Wan, J. Ma, Z. Wang, W. Zhou and S. Kaliaguine, Appl. Catal., B, 2005, 59, 235-242.

95 Z. Zhang, M. Chen, Z. Jiang and W. Shangguan, J. Environ. Sci., 2010, 22, 1441-1446.

96 Y. Zheng, M. Li, D. Wang, M. P. Harold and D. Luss, Catal. Today, 2016, 267, 192-201.

97 X. Cheng and X. T. Bi, Chem. Eng. J., 2012, 211, 453-462.

98 S. E. Maisuls, L. Lefferts, K. Seshan, T. Furusawa, K. Aika, B. Mosqueda-Jimenez and J. A. Lercher, Catal. Today, 2003, 84, 139-147.

99 R. Burch and P. J. Millington, Catal. Today, 1995, 26, 185206.

100 H. Hamada, Catal. Today, 1994, 22, 21-40.

101 W. Schießer, H. Vinek and A. Jentys, Appl. Catal., B, 2001, 33, 263-274.

102 E. Joubert, X. Courtois, P. Marecot, C. Canaff and D. Duprez, J. Catal., 2006, 243, 252-262.

103 Y. Chi and S. S. Chuang, Catal. Today, 2000, 62, 303-318.

104 V. A. Sadykov, V. V. Lunin, V. A. Matyshak, E. A. Paukshtis, A. Y. Rozovskii, N. N. Bulgakov and J. R. H. Ross, Kinet. Catal., 2003, 44, 379-400.

105 J. T. Miller, E. Glusker, R. Peddi, T. Zheng and J. R. Regalbuto, Catal. Lett., 1998, 51, 15-22.

106 D. K. Captain, K. L. Roberts and M. D. Amiridis, Catal. Today, 1998, 42, 93-100.

107 M. D. Amiridis, K. L. Roberts and \&C. J. Pereira, Appl. Catal., $B$, 1997, 14, 203-209.

108 A. V. Kucherov, C. N. Montreuil, T. N. Kucherova and M. Shelef, Catal. Lett., 1998, 56, 173-181. 